\title{
Relationship between Manure Management Application Practices and Phosphorus and Nitrogen Export in Snowmelt Run-off Water from a Black Chernozem Saskatchewan Soil
}

\author{
Tom King ${ }^{1}$, Jeff Schoenau ${ }^{1} \&$ Jane Elliott ${ }^{2}$ \\ ${ }^{1}$ Department of Soil Science, 51 Campus Drive, University of Saskatchewan, Saskatoon, SK S7N 5A8, Canada \\ ${ }^{2}$ Environment and Climate Change Canada, 11 Innovation Blvd., Saskatoon, SK S7N 3H5, Canada \\ Correspondence: Jeff Schoenau, Department of Soil Science, 51 Campus Drive, University of Saskatchewan, \\ Saskatoon, SK S7N 5A8, Canada. E-mail: jeff.schoenau@usask.ca
}

Received: October 31, 2016 Accepted: March 3, 2017 Online Published: March 30, 2017

doi:10.5539/sar.v6n2p93

URL: https://doi.org/10.5539/sar.v6n2p93

\begin{abstract}
In Saskatchewan, soil nutrients released from land-applied solid cattle manure (SCM) and liquid hog manure (LHM) could be subject to off-field export via spring surface run-off water and/or subsurface leaching from melting snow. The objective of this study was to determine how the placement of SCM and LHM using surface and subsurface application methods affects the amounts of soluble reactive phosphorus (SRP), nitrate-nitrogen (NO3-N) and ammonium nitrogen (NH4-N) exported in simulated snowmelt run-off. Intact soil slabs were collected post-harvest in Oct. 2008 and Oct. 2009 from an annually cropped Black Chernozem in east-central Saskatchewan having treatments of: 1) a control, with no SCM or urea fertilizer added and 2) SCM applied at a rate of $60.6 \mathrm{t}$ ha- 1 for 2 years as: surface broadcast, broadcast and incorporated and subsurface banded. For comparison purposes, intact soil slab monoliths were collected post-harvest in Oct. 2009 from an annually cropped Black Chernozem in east-central Saskatchewan having treatments of: 1) a control, with no LHM or urea fertilizer added; 2) LHM broadcast and incorporated at a rate of 37,000 L ha-1 for 12 years; and 3) LHM subsurface banded at rates of 37,000 L ha-1 and 148,000 L ha-1 for 12 years. Run-off water and leachate were collected under two different simulated prairie spring melt conditions: 1 ) thawing soil slabs containing snow that slowly melted on the surface; and 2) frozen soil slabs with run-off water applied to the surface and allowed to run-off across the frozen soil surface. Export of SRP in the thawing soil slabs that had SCM applied in subsurface bands was $0.51 \mathrm{~kg}$ P ha- 1 and was significantly higher than the non-manured control (0.07 kg P ha- 1$)$. Dissolved NO3-N exported in water running across the frozen soil slabs was highest in the broadcast and incorporated treatment $(0.30 \mathrm{~kg} \mathrm{~N}$ ha-1). All SCM manured treatments had higher export of nitrate $(0.2-0.25 \mathrm{~kg}$ NO3-N ha-1) compared to the non-manured control $(0.07 \mathrm{~kg}$ ha- 1$)$. There was no significant $(\mathrm{P} \leqslant 0.10)$ effect of placement method on SRP, NO3-N and NH4-N export on thawing or frozen SCM soil slabs. Export of SRP was less in LHM treatments than SCM treatments. In thawing soil slabs with 148,000 L ha-1 LHM treatment, the $\mathrm{P}$ export was $0.05 \mathrm{~kg} \mathrm{P}$ ha- 1 and was greater than the control treatment $(0.01 \mathrm{~kg}$ ha- 1$)$. Rate of application and manure type appears to be more important than method of placement in influencing $\mathrm{P}$ and $\mathrm{N}$ transport in melt water on these soils.
\end{abstract}

Keywords: solid cattle manure, liquid hog manure, soluble reactive phosphorus, nitrate-nitrogen, ammonium-nitrogen, snowmelt runoff

\section{Introduction}

Application of animal manure for its nutrient content and ability to aid in building soil organic matter is a common practice in western Canada in locations where animal manures are abundant. Nutrients such as phosphorus $(\mathrm{P})$ and nitrogen $(\mathrm{N})$ in manures can be effectively utilized for crop production. However, in soils receiving large application rates of animal manures, elevated transport of dissolved and particulate $\mathrm{P}$ and $\mathrm{N}$ off-field by water can be of concern in soils that become overloaded in these nutrients. For example, since the 1980s; the health of Lake Winnipeg has decreased due to excessive dissolved P and N loading from non-point sources including natural ecosystems, urban sources, atmospheric deposition as well as surrounding agricultural systems (Lake Winnipeg Stewardship Board, 2006). Beneficial management practices have been identified in an 
attempt to reduce the excess nutrients exported offsite to surface and subsurface water bodies (Schnepf and Cox, 2006). Much attention has been directed towards controlling point source contamination of surface and subsurface water bodies; however, non-point source contamination, such as off-field movement of nutrients from golf courses, urban lawns and agricultural fields, into surface and subsurface water bodies is difficult to identify and control (Sharpley et al., 2001).

Some agricultural fields have evolved from serving as sinks for nutrients such as $\mathrm{P}$ and $\mathrm{N}$, to nutrient sources due to fertilizer application beyond crop nutrient demand (Sharpley et al., 2001). The desired $\mathrm{P}$ and $\mathrm{N}$ nutrient management in agriculture is to meet crop nutrient demand with little residual nutrient that is susceptible to loss mechanisms such as leaching, denitrification or export from the field in water. Practicing no-till soil conservation has been identified as one management method that reduces the amount of particulate nutrients carried by eroding sediment that is removed from agricultural fields, and this practice has been widely adopted by growers on the Canadian prairies. However, it was reported early on that dissolved nutrients can be more easily exported via surface and subsurface water in these minimal low disturbance (Baker and Laflen, 1983; Langdale et al., 1985; Sharpley and Smith, 1994; Zhao et al., 2001).

There has been a desire to more closely monitor and control the dissolved $\mathrm{P}$ movement off fields receiving annual or semi-annual applications of animal manure (Sharpley et al., 2005). Agricultural fields that are under a no-till management have been documented as having greater dissolved P losses in surface run-off, compared to conventional tilled fields due to the stratification of P with depth (Mueller et al., 1984; Sharpley and Smith, 1994), with a greater amount of $P$ being concentrated in the upper surface portion of the soil (Butler and Coale, 2005; Guertal et al., 1991; Tiessen et al., 2010). Sharpley et al. (2005) observed strong correlation between P losses in run-off water and soil $\mathrm{P}$ availability at the $0.1-3.7 \mathrm{~cm}$ depth; namely as soil $\mathrm{P}$ increased in this zone, the greater the observed potential for soil release of $\mathrm{P}$ to run-off water which has also been reported elsewhere (Vadas et al., 2005).

Phosphorus and $\mathrm{N}$ export in run-off water can be affected by the rate, method and seasonal timing of manure application. Phosphorus and N in manures such as SCM or LHM that are directly applied to the soil surface without incorporation, may not interact with soil particles that would otherwise help to retain them through adsorption and formation of insoluble complexes (Vadas et al., 2004). Mooleki et al. (2002) reported greater crop yields and larger $\mathrm{N}$ recovery when LHM was subsurface banded compared to broadcast applications. Some studies have reported that the timing of animal manure application influences the forms and/or amounts of nutrients exported offsite. Klausner et al. (1976) suggested that fall pre-snowfall application of manure reduces $\mathrm{N}$ nutrient loss compared to winter manure application. When manure is applied during the spring prior to field operations (e.g., tillage, seeding and harrowing) the manure $\mathrm{P}$ is incorporated into the soil, which is commonly believed to reduce the amount of $\mathrm{P}$ exported via run-off.

A large portion of the nutrient loss research has been conducted in areas of Canada or the United States where run-off from rainfall events accounts for the majority of nutrient export. Previous research conducted in western Canada has reported that soil losses from spring snowmelt can be greater than erosion from rainfall (Chanasyk and Woytowich, 1987; McConkey et al., 1997; Van Vliet and Hall, 1991). In regions of the northern Great Plains such as Saskatchewan, spring snowmelt is the major moisture recharge event of the year. Snowfall can account for as much as $30 \%$ of the annual precipitation received (Cutforth et al., 1999) and accumulates through several months, subsequently melting and running over thawing and frozen soil when spring temperatures begin to increase (Li et al., 2011). Snowmelt run-off can exceed rainfall run-off due to frozen soils with limited water infiltration (Granger et al., 1984; Hansen et al., 2000; Young and Mutchler, 1976). The prolonged period in which snowmelt occurs favors more saturated conditions within the soil surface, which enhances the release of dissolved nutrient forms (Bechmann et al., 2005; Little et al., 2007; Ontkean et al., 2005).

Snowmelt run-off has less erosive ability compared to run-off from rainfall. The kinetic energy generated by the force of raindrops contacting the soil surface can cause more aggregate breakdown, soil particle detachment and movement of particles with the run-off water (Li et al., 2011). Glozier et al. (2006) reported that approximately two-thirds of the $\mathrm{N}$ and $\mathrm{P}$ removal due to run-off from snowmelt in southern Manitoba occurred in a dissolved inorganic form. Little et al. (2007) reported that in Alberta, Canada, over $90 \%$ of the P removed by spring snowmelt was in a dissolved inorganic form. Fleming and Fraser (2000) have reported that frozen or unthawed bare soils do not allow infiltration of nutrients such as $\mathrm{P}$ and $\mathrm{N}$. Research has also been conducted into subsurface pathways for P loss (Sims et al., 1998). Jensen et al. (1998) and Stamm et al. (1998) have reported that most of the P leaching is likely through shallow macropore preferential flow. In soils that are thawing at the surface but remain frozen underneath in early spring, much of the flow below the soil surface may be lateral flow above the frozen layer. Valipour (2012a) noted that there is some error that can occur when estimating subsurface 
drainage (Gallichand, 1994) watertable depth that results from the vertical variation of hydraulic conductivity in soil. Annual applications of animal manures could lead to elevated concentrations of $\mathrm{P}$ and $\mathrm{N}$ nutrients that can become phytotoxic (Valipour and Singh, 2016). Forecasting and determination of the amount of annual moisture to be received in a region (Valipour, 2016) is important along with the water use efficiency of different types of crops and cropping patterns to gain an understanding of the potential for runoff and leaching of water and soil nutrients that could be potentially moved off a field site (Valipour, 2012b; Valipour, 2013a). Volume of water received from annual moisture deposits, moisture distribution and uniformity, deep percolation losses and water use efficiency by various crops (Valipour, 2013b) will contribute to amounts of nutrients that can potentially be exported from a cultivated field site.

Despite several Saskatchewan studies that have examined $\mathrm{P}$ and $\mathrm{N}$ in spring snowmelt, it is evident that limited information exists specifically on the nature and extent of SRP and $\mathrm{N}$ transport in snowmelt water in soils receiving animal manure in surface and subsurface banded type application methods in western Canada. Even less information exists regarding multi-year animal manure applications at different rates and the effect of different application methods. Priyashantha et al. (2007) investigated the movement of $\mathrm{P}$ and $\mathrm{N}$ over a Saskatchewan landscape in snowmelt runoff in an enclosed 0.8 ha basin receiving hog manure in two fall applied applications. Soil core samples were obtained and air dried and sieved to $<2.0 \mathrm{~mm}$, thus samples were disturbed before being analyzed. Smith et al. (2011) examined $\mathrm{P}$ and $\mathrm{N}$ in spring snowmelt runoff in standing water in depression zone areas of a one year in-field cattle feeding enclosure located in east-central Saskatchewan. Cade-Menun et al. (2012) measured $\mathrm{P}$ and $\mathrm{N}$ nutrient loss in snowmelt from commercially fertilized no-till managed annual wheat-canola crop rotation and perennial pasture land in Saskatchewan. Subsurface injection or banding of manure can be beneficial to a crop, such as increased plant nutrient uptake, increased bioavailability of soil nutrients and enhanced crop growth. However the effects on $\mathrm{P}$ and $\mathrm{N}$ nutrient export snowmelt runoff in fields that have received multiple year SCM and LHM subsurface banded applications have not been evaluated in western Canadian soils.

A novel methodology was developed for collecting intact soil slab monoliths from replicated field plots. This involved the intact extraction of a slab of soil after harvest operations had been concluded that could be transported to the lab to measure the amounts of SRP and N contained in runoff and leachate water. This was followed by the development of a technique for simulating melting snow conditions and run-off under two common early spring scenarios: 1) where snowmelt water is allowed to infiltrate and move laterally below the soil surface in thawing soil and 2) a condition in which melt water moves rapidly across a frozen surface. It was hypothesized that $\mathrm{P}$ and $\mathrm{N}$ movement from soil amended with manure would be enhanced compared to unamended controls, that in-soil placement would reduce nutrient export in surface run-off, greater export of $\mathrm{P}$ would occur from SCM amended soil, and that export would be greater from snow melting on thawing soil that allows the snowmelt water to interact with the soil compared to melt water rapidly passing across frozen soil. Therefore the objective of the research was to determine the effect of surface and subsurface water flow arising from snowmelt on the nutrient export from soils with different manure management histories.

\section{Method}

\subsection{Experimental Site}

The SCM and LHM studies were conducted near Dixon, Saskatchewan (Dixon site) on two adjacent areas of the same field $\left(52^{\circ} 11^{\prime} 54^{\prime \prime} \mathrm{N} 105^{\circ} 14^{\prime} 10^{\prime \prime} \mathrm{W}\right)$ within the Rural Municipality of Humboldt. The soil at the site belongs to the Cudworth Association and is a Black Chernozemic soil formed in calcareous, silty, lacustrine parent materials and having a loam surface texture (Saskatchewan Soil Survey 1989). The soil at this site occurs on a gently sloping land surface and has a few limitations that hinder agricultural activity. Identified limitations include insufficient moisture holding capacity and some salinity (covering 10-20\% of the landscape), occurring mostly in sloughs and low lying areas (Saskatchewan Soil Survey, 1989). Soil pH in the 0-15 cm depth is 7.9, electrical conductivity is $0.1 \mathrm{dS} \mathrm{m}^{-1}$ and soil organic carbon is $2.5 \%$. This field site is only slightly stony and has a low susceptibility to wind and water erosion (Saskatchewan Soil Survey, 1989).

\subsection{Manure Treatments and Experimental Design}

The SCM injection study at Dixon was established before spring seeding operations commenced in June 2007, with SCM applied using Prairie Agricultural Machinery Institute's (PAMI) SCM subsurface banding applicator machine. The SCM field trial plots $(3.05 \times 6.09 \mathrm{~m})$ were set up as a randomized complete block design, replicated four times. The SCM treatments were applied in June 2007, May 2008 and May 2009. Treatments included an undisturbed control plot with no manure or fertilizer applied, and another control with no manure or fertilizer applied but with disturbance of the soil using the coulter openers of the SCM injector machine. The 
SCM was applied using three application procedures; 1) broadcast application where SCM was applied on the soil surface (no incorporation), 2) broadcast and incorporated where SCM was applied on the soil surface and then incorporated using a disk, 3) subsurface banding, where SCM was subsurface placed in bands using the PAMI SCM bander machine (in six subsurface trenches with $60 \mathrm{~cm}$ coulter openers spaced $30 \mathrm{~cm}$ apart, applying the SCM product in bands $10-13 \mathrm{~cm}$ in depth). Twenty $\mathrm{cm}$ closing wheels covered the exposed or banded trench with soil. The rate of SCM applied was equal to $300 \mathrm{~kg}$ total $\mathrm{N} \mathrm{ha}^{-1}$, at a rate of approximately $60.6 \mathrm{tha}^{-1}$, and may be considered triple the rate of annually applied $\mathrm{N}$ (approximately $100 \mathrm{~kg} \mathrm{~N} \mathrm{ha}^{-1}$ ) that would be recommended as commercial fertilizer to meet typical crop requirements in the canola-oat rotation.

The SCM applied in the three-year field trial was obtained from the Poundmaker Feedlot, which is located approximately $8 \mathrm{~km}$ east of the town of Lanigan, SK. Phosphorus and N contents of the SCM applied in 2007, 2008 and 2009 are listed in Table 1. Due to variation in manure P content over the years, the P applied in the SCM treatments ranged from $160 \mathrm{~kg} \mathrm{P} \mathrm{ha}^{-1}$ in 2007 to $150 \mathrm{~kg} \mathrm{P} \mathrm{ha}^{-1}$ in 2008 to $213 \mathrm{~kg} \mathrm{P}^{-1}$ in 2009 (Table 1). Applied Total $\mathrm{N}$ in the SCM ranged from $300 \mathrm{~kg} \mathrm{~N} \mathrm{ha}^{-1}$ in 2007 to $180 \mathrm{~kg} \mathrm{~N} \mathrm{ha}^{-1}$ in 2008 to $561 \mathrm{~kg} \mathrm{~N} \mathrm{ha}^{-1}$ in 2009. Possible changes in animal nutrition management between the three years of collected manure could have led to the yearly variations in animal manure $\mathrm{P}$ and $\mathrm{N}$ nutrient contents. Applied ammonium-nitrogen $\left(\mathrm{NH}_{4}-\mathrm{N}\right)$ in the SCM was $0.15 \mathrm{~kg} \mathrm{NH}_{4}-\mathrm{N} \mathrm{ha}^{-1}$ in 2007 and 2008, and $0.18 \mathrm{~kg} \mathrm{NH}_{4}-\mathrm{N} \mathrm{ha}^{-1}$ in 2009.

The LHM trials that were sampled for comparison purposes were established in October of 1996. In this trial, each year after harvesting operations were completed, application of LHM was made using PAMI's LHM subsurface injector applicator truck as described by Mooleki et al. (2002). Soil slab monolith collection was conducted in Oct. 2009 prior to application of LHM. The LHM field trial plots (3.05 x $30.48 \mathrm{~m}$ ) were set up as a randomized complete block design and replicated four times. Treatments were applied in October, post-harvest, every year for the duration of the 12-year long-term LHM study. The field was seeded to canola in late May of 2008, and to barley (Hordeum vulgare) in early June 2009. Treatments included a control plot with no manure or fertilizer being applied and disturbance of the soil using the coulter openers of the PAMI LHM subsurface injection applicator truck. Liquid hog manure was applied using two application procedures; 1) subsurface injection where LHM was subsurface banded and placed in a band using the PAMI LHM subsurface injection machine in six subsurface bands using $60 \mathrm{~cm}$ diameter coulter openers spaced $30 \mathrm{~cm}$ apart applying the LHM 10-13 cm deep, and 2) broadcast of LHM across the soil surface followed by incorporation after $24 \mathrm{hr}$.

Table 1. Rates of phosphorus, total N and ammonium N applied as manure from 2007-2009 in the solid cattle manure trials at Dixon, Saskatchewan

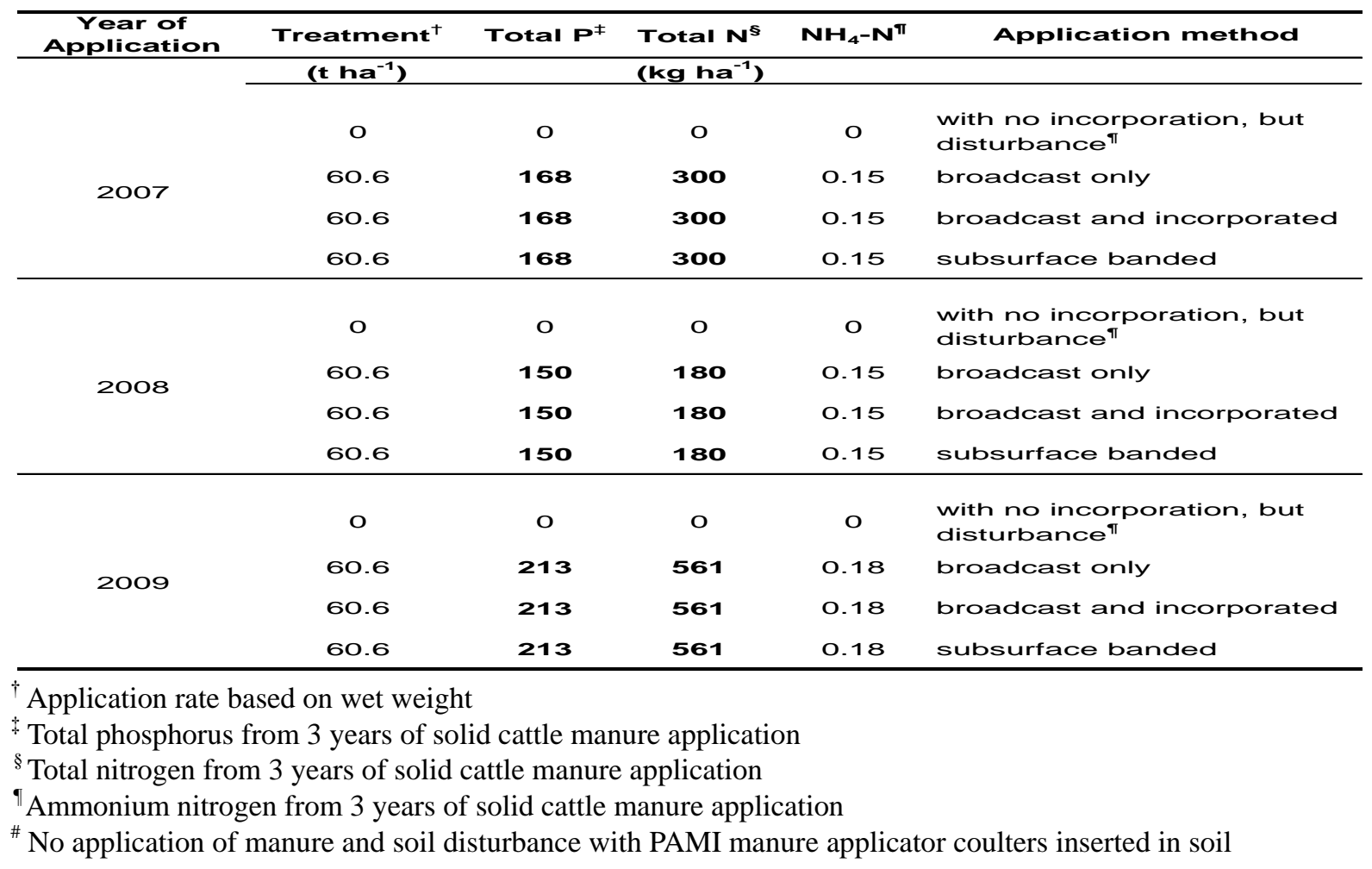


Manure sub-samples for both the SCM and LHM applications for each year of application were obtained from the application equipment at the time of treatment application in the field plots. From 1997-2007, the annual application rates of LHM were approximately $90\left(37,000 \mathrm{~L} \mathrm{ha}^{-1}\right)$ and $350\left(148,000 \mathrm{~L} \mathrm{ha}^{-1}\right) \mathrm{kg}^{-2}$ total N ha ${ }^{-1}$ per year, and $6 \mathrm{~kg}$ total $\mathrm{Pha}^{-1}$ and $25 \mathrm{~kg}$ total $\mathrm{P} \mathrm{ha}^{-1}$ per year on the low and high rate treatments respectively (Table 2). The total $\mathrm{N}$ that was applied in the 12-year long-term LHM trial in the years that encompassed this study (2008 and 2009) slightly ranged from $68 \mathrm{~kg} \mathrm{~N} \mathrm{ha}^{-1}$ in the 2008 low application rate treatment to $79 \mathrm{~kg} \mathrm{~N} \mathrm{ha}^{-1}$ in 2009, while total P ranged from $4 \mathrm{~kg} \mathrm{Pha}^{-1}$ to $7 \mathrm{~kg} \mathrm{P} \mathrm{ha}^{-1}$ in the same treatments (Table 2). Phosphorus that was added over the 12 years in the LHM treatments at the $37,000 \mathrm{~L} \mathrm{ha}^{-1}$ rate was $73 \mathrm{~kg} \mathrm{P} \mathrm{ha}^{-1}$ and added at the $148,000 \mathrm{~L} \mathrm{ha}^{-1}$ rate was $292 \mathrm{~kg} \mathrm{Pha}^{-1}$. Subsurface banding of LHM at four times that of the low application rate substantially increased $\mathrm{P}$ and $\mathrm{N}$ being added to the soil (Table 2). Subsurface banding of LHM at four times the normal low application rate increased the amount of $\mathrm{P}$ and $\mathrm{N}$ being added to the soil. For example, in 2009, total $\mathrm{P}$ being added to the soil by LHM subsurface banding application method increased from $7 \mathrm{~kg} \mathrm{ha}^{-1}$ in the low rate $37,000 \mathrm{~L} \mathrm{ha}^{-1}$ subsurface banding application method to $28 \mathrm{~kg} \mathrm{ha}^{-1}$ in the $148,000 \mathrm{~L} \mathrm{ha}^{-1}$ subsurface banding method. In the same year, total $\mathrm{N}$ being added to the soil by LHM subsurface banding application method increased from $79 \mathrm{~kg} \mathrm{ha}^{-1}$ in the low rate $37,000 \mathrm{~L} \mathrm{ha}^{-1}$ subsurface banding application method to $316 \mathrm{~kg} \mathrm{ha}^{-1}$ in the $148,000 \mathrm{~L} \mathrm{ha}^{-1}$ subsurface banding method (Table 2).

Table 2. Treatments from 1997-2007, 2008 and 2009 in the twelve-year liquid hog manure study at Dixon, Saskatchewan

\begin{tabular}{|c|c|c|c|c|c|}
\hline $\begin{array}{c}\text { Year of } \\
\text { Application }\end{array}$ & Treatment $^{\dagger}$ & P rate ra $^{\ddagger}$ & $\begin{array}{c}\text { Total N } \\
\text { rate }^{\S}\end{array}$ & $\begin{array}{l}\mathrm{NH}_{4}-\mathrm{N} \\
\text { rate }\end{array}$ & Application method \\
\hline \multirow{5}{*}{ 1997-2007 } & $\left(L_{h a}^{-1}\right)$ & & $\left(\mathrm{kg} \mathrm{ha}^{-1}\right)$ & & \\
\hline & 0 & 0 & 0 & 0 & $\begin{array}{l}\text { with no incorporation, but } \\
\text { disturbance }\end{array}$ \\
\hline & 37,000 & 62 & 875 & 650 & \multirow{2}{*}{$\begin{array}{l}\text { hog manure subsurface } \\
\text { injected }\end{array}$} \\
\hline & 148,000 & 248 & 3500 & 2600 & \\
\hline & 37,000 & 62 & 875 & 650 & $\begin{array}{l}\text { hog manure broadcast and } \\
\text { incorporated }\end{array}$ \\
\hline \multirow{4}{*}{2008} & 0 & 0 & 0 & 0 & $\begin{array}{l}\text { with no incorporation, but } \\
\text { disturbance }{ }^{\#}\end{array}$ \\
\hline & 37,000 & 4 & 68 & 61 & \multirow{2}{*}{$\begin{array}{l}\text { hog manure subsurface } \\
\text { injected }\end{array}$} \\
\hline & 148,000 & 16 & 272 & 244 & \\
\hline & 37,000 & 4 & 68 & 61 & $\begin{array}{l}\text { hog manure broadcast and } \\
\text { incorporated }\end{array}$ \\
\hline \multirow{4}{*}{2009} & 0 & 0 & 0 & 0 & $\begin{array}{l}\text { with no incorporation, but } \\
\text { disturbance }\end{array}$ \\
\hline & 37,000 & 7 & 79 & 69 & \multirow{2}{*}{$\begin{array}{l}\text { hog manure subsurface } \\
\text { injected }\end{array}$} \\
\hline & 148,000 & 28 & 316 & 276 & \\
\hline & 37,000 & 7 & 79 & 69 & $\begin{array}{l}\text { hog manure broadcast and } \\
\text { incorporated after } 24 \mathrm{~h}\end{array}$ \\
\hline
\end{tabular}

\subsection{Measurements and Procedures}

2.3.1 Soil Sampling and Analysis

Soil samples from the SCM study and 12 year long-term LHM study were obtained from each of the treatment plots post-harvest in Oct. 2008 and Oct. 2009 using a truck mounted soil sampling coring device. Soil samples 
were analyzed for available nitrate-nitrogen $\left(\mathrm{NO}_{3}-\mathrm{N}\right)$ and $\mathrm{NH}_{4}-\mathrm{N}$ by extracting with $2 M$ potassium chloride and measuring the ion concentrations colorimetrically using a Technicon Autoanalyzer II (Keeney and Nelson, 1982). Soil extractable P was determined by a modified Kelowna method (Qian et al., 1994).

The 2008 extracable P measured in the $0-15 \mathrm{~cm}$ depth in the $60.6 \mathrm{t} \mathrm{ha}^{-1} \mathrm{SCM}$ application rate was $93.3 \mathrm{~kg} \mathrm{ha}^{-1}$ in the broadcast and incorporated applicat160ion method and increased to $145.9 \mathrm{~kg} \mathrm{ha}^{-1}$ in the subsurface banded and $150.1 \mathrm{~kg} \mathrm{ha}^{-1}$ in the broadcast only application method (Table 3).

Table 3. Extractable soil nutrients $(0-15 \mathrm{~cm})$ in the solid cattle manure trials sampled post-harvest in 2008 and 2009 at Dixon, Saskatchewan

\begin{tabular}{|c|c|c|c|c|c|c|c|c|}
\hline \multirow[t]{2}{*}{$\begin{array}{c}\text { Year of } \\
\text { Application }\end{array}$} & \multirow{2}{*}{$\frac{\text { Treatment }^{\dagger}}{\left(\mathrm{t} \mathrm{ha}^{-1}\right)}$} & \multicolumn{2}{|c|}{ MKP $^{\ddagger}$} & \multicolumn{2}{|c|}{$\mathrm{NO}_{3}-\mathrm{N}$} & \multicolumn{2}{|c|}{$\mathrm{NH}_{4}-\mathrm{N}$} & \multirow[t]{2}{*}{ Application method } \\
\hline & & & & (kg & $\mathrm{ha}^{-1}$ ) & & & \\
\hline \multirow{4}{*}{2008} & 0 & $23.5^{\S}$ & $(9.6)^{\pi}$ & 5.5 & (1.7) & 13.1 & (3.8) & $\begin{array}{l}\text { with no incorporation, but } \\
\text { disturbance }{ }^{\#}\end{array}$ \\
\hline & 60.6 & 150.1 & $(51.1)$ & 11.1 & (1.9) & 10.6 & (3.3) & broadcast only \\
\hline & 60.6 & 93.3 & $(73.7)$ & 9.1 & $(5.2)$ & 10.9 & (3.2) & broadcast and incorporated \\
\hline & 60.6 & 145.9 & $(73.6)$ & 9.7 & (4.3) & 12.7 & (2.7) & subsurface banded \\
\hline & $\operatorname{LSD}_{(0.10)}{ }^{\dagger \dagger}$ & 56.2 & & 3.0 & & 3.0 & & \\
\hline \multirow{5}{*}{2009} & 0 & 19.8 & (6.6) & 4.6 & $(0.4)$ & 8.3 & (1.2) & \multirow{4}{*}{$\begin{array}{l}\text { with no incorporation, but } \\
\text { disturbance } \\
\text { cattle manure broadcast } \\
\text { only } \\
\text { cattle manure broadcast } \\
\text { and incorporated } \\
\text { cattle manure subsurface } \\
\text { banded }\end{array}$} \\
\hline & 60.6 & 222.2 & (36.8) & 10.3 & (1.6) & 7.1 & (1.7) & \\
\hline & 60.6 & 177.1 & $(20.6)$ & 9 & (1.7) & 8.2 & (1.9) & \\
\hline & 60.6 & 204.9 & (127.3) & 11.4 & (3.5) & 9.5 & $(4.2)$ & \\
\hline & $\operatorname{LSD}_{(0.10)}$ & 81.4 & & 3.2 & & 2.2 & & \\
\hline
\end{tabular}

${ }^{\dagger}$ Application rate based on wet weight

$\$$ Modified Kelowna extractable P

$\S$ Means in the first column

"Standard deviations $( \pm)$ of the mean in the second column

\# No application of manure and soil disturbance with PAMI manure applicator inserted in soil

${ }^{\dagger}$ Least significant difference $(P \leq 0.10)$

The extractable $\mathrm{P}$ measured in the $0-15 \mathrm{~cm}$ depth post-harvest at the 3 year SCM site increased to over $170 \mathrm{~kg} \mathrm{P}$ $\mathrm{ha}^{-1}$ in the three manure treatments by fall 2009 compared to about $20 \mathrm{~kg} \mathrm{P} \mathrm{ha}^{-1}$ in the unmanured control plots (Table 3), reflecting the high amount of $\mathrm{P}$ added in the cattle manure. Only a small amount of inorganic $\mathrm{N}$ accumulated in the soil from the application of SCM, and soil extractable $\mathrm{NO}_{3}-\mathrm{N}$ levels in the SCM site were 9-11 $\mathrm{kg} \mathrm{NO}_{3}-\mathrm{N} \mathrm{ha}^{-1}$ in the three manure treatments in both the fall of 2008 and 2009 (Table 3). Soil extractable $\mathrm{NH}_{4}-\mathrm{N}$ decreased slightly from $10 \mathrm{~kg} \mathrm{NH}_{4}-\mathrm{N} \mathrm{ha}^{-1}$ in the three treatments in 2008 to less than $9 \mathrm{~kg} \mathrm{NH}_{4}-\mathrm{N} \mathrm{ha}^{-1}$ in 2009 (Table 3). Low accumulations of ammonium and nitrate in the soil are anticipated with SCM due to low ammonium content and large amount of organic $\mathrm{N}$ that mineralizes only very slowly.

Soil extractable P measured in the 0-30 cm depth post-harvest at the 12 year LHM site, prior to LHM application in fall 2008 and 2009 was similar among treatments in 2008 and 2009. In 2008, MK-P ranged from $20.7 \mathrm{~kg} \mathrm{P}$ $\mathrm{ha}^{-1}$ in the low rate broadcast and incorporated to $31.3 \mathrm{~kg} \mathrm{P} \mathrm{ha}^{-1}$ in the high rate subsurface banded versus $24.6 \mathrm{~kg}$ $\mathrm{P} \mathrm{ha}^{-1}$ in the unmanured control (Table 4). Soil extractable P levels in the LHM treatments in the fall of 2009 were similar, and slightly lower than in the fall of 2008. Lack of large influence of long-term application of LHM on soil extractable P content is consistent with amounts of P added in LHM over the years ( 5 to $25 \mathrm{~kg} \mathrm{Pha}^{-1} \mathrm{yr}^{-1}$ ) that are similar to $\mathrm{P}$ removed in crop harvest each year.

Soil extractable $\mathrm{NO}_{3}-\mathrm{N}$ levels in fall of 2008 in the $0-30 \mathrm{~cm}$ depth at the $\mathrm{LHM}$ site were $9.3 \mathrm{~kg} \mathrm{NO}_{3}-\mathrm{N} \mathrm{ha}^{-1}$ in the 
control treatment and $12.6 \mathrm{~kg} \mathrm{NO}_{3}-\mathrm{N} \mathrm{ha}^{-1}$ in the 2009 control treatment (Table 4). In the 2008 low rate broadcast and incorporate, soil extractable $\mathrm{NO}_{3}-\mathrm{N}$ levels $50.7 \mathrm{~kg} \mathrm{NO}_{3}-\mathrm{N} \mathrm{ha}^{-1}$ in the low rate subsurface banded and $266 \mathrm{~kg}$ $\mathrm{NO}_{3}-\mathrm{N} \mathrm{ha}^{-1}$ in the high rate subsurface banded treatment (Table 4). In the 2009 high rate broadcast and incorporate, soil extractable $\mathrm{NO}_{3}-\mathrm{N}$ levels $118.7 \mathrm{~kg} \mathrm{NO}_{3}-\mathrm{N}^{-1}$. Soil extractable $\mathrm{NO}_{3}-\mathrm{N}$ was increased when LHM was subsurface banded applied at four times the low rate subsurface banding treatment.

Soil extractable $\mathrm{NH}_{4}-\mathrm{N}$ in the 0-30 cm depth was 24-26 kg NH $4-\mathrm{N} \mathrm{ha}^{-1}$ in three LHM treatments and the control in 2008. In fall 2009 samples, soil extractable $\mathrm{NO}_{3}-\mathrm{N}$ levels were again about four times higher in the high rate subsurface banded soils compared to the lower rate treated plots (Table 4). Accumulation of nitrate rather than phosphate in the LHM soil is expected with 12 years of annual addition of about $300 \mathrm{~kg} \mathrm{~N} \mathrm{ha}^{-1}$, which is an amount that greatly exceeds removal in crop harvest.

Table 4. Extractable soil nutrients $(0-30 \mathrm{~cm})$ in the liquid hog manure trials that were sampled post-harvest in 2008 and 2009 at Dixon, Saskatchewan

\begin{tabular}{|c|c|c|c|c|c|c|c|c|}
\hline \multirow[t]{2}{*}{$\begin{array}{c}\text { Year of } \\
\text { Application }\end{array}$} & \multirow{2}{*}{$\frac{\text { Treatment }^{\dagger}}{\left(\mathrm{L} \mathrm{ha}^{-1}\right)}$} & \multicolumn{2}{|c|}{$\mathrm{MKP}^{\ddagger}$} & \multicolumn{2}{|c|}{$\mathrm{NO}_{3}-\mathrm{N}$} & \multicolumn{2}{|c|}{$\mathrm{NH}_{4}-\mathrm{N}$} & \multirow[t]{2}{*}{ Application method } \\
\hline & & & & $(\mathrm{kg}$ & $\mathrm{ha}^{-1}$ ) & & & \\
\hline \multirow{5}{*}{2008} & 0 & $24.6^{\S}$ & $(15.0)^{\pi}$ & 9.3 & (1.8) & 26.4 & $(5.4)$ & $\begin{array}{l}\text { with no incorporation, but } \\
\text { disturbance }{ }^{\#}\end{array}$ \\
\hline & 37,000 & 26.4 & (12.9) & 50.7 & (16.5) & 25.0 & $(8.5)$ & hog manure subsurface \\
\hline & 148,000 & 31.3 & (16.4) & 266.4 & (231.6) & 26.4 & $(5.8)$ & injected \\
\hline & 37,000 & 20.7 & $(8.3)$ & 11.7 & $(4.5)$ & 24.3 & $(5.5)$ & $\begin{array}{l}\text { hog manure broadcast and } \\
\text { incorporated }\end{array}$ \\
\hline & $\operatorname{LSD}_{(0.10)}{ }^{\dagger \dagger}$ & 11.6 & & 87.2 & & 5.2 & & \\
\hline \multirow{5}{*}{2009} & 0 & 24.6 & (8.6) & 12.6 & (4.6) & 16.9 & $(9.6)$ & $\begin{array}{l}\text { with no incorporation, but } \\
\text { disturbance }^{\#}\end{array}$ \\
\hline & 37,000 & 21.1 & (5.7) & 28.0 & $(10.0)$ & 39.2 & $(38.2)$ & hog manure subsurface \\
\hline & 148,000 & 28.0 & (8.0) & 118.5 & (78.3) & 17.5 & $(9.6)$ & injected \\
\hline & 37,000 & 17.3 & (3.2) & 11.3 & $(0.9)$ & 30.8 & $(11.8)$ & $\begin{array}{l}\text { hog manure broadcast and } \\
\text { incorporated }\end{array}$ \\
\hline & $\operatorname{LSD}_{(0.10)}$ & 6.4 & & 25.5 & & 14.5 & & \\
\hline
\end{tabular}

$\dagger$ Application rate based on wet weight

Modified Kelowna extractable P

${ }^{\S}$ Standard deviations of the mean

${ }^{\mathbb{I}}$ No application of manure and PAMI manure applicator coulters inserted in soil

\# Least significant difference $(P \leq 0.10)$

\subsubsection{Snowmelt and Water Run-off Simulation on Soil Slab Monoliths}

Soil slab monolith samples for the thawing soil slab snowmelt portion of the study were collected at random positions within each treatment plot in mid-Oct. 2008 and mid-Oct. 2009, after harvest operations had concluded for each of those crop years in the SCM study, and in mid-Oct. 2009 after harvest operations had concluded in the 12- year long-term LHM study. Single soil slab monolith samples for the frozen soil slab water run-off portion of the SCM study were collected in mid-Oct. 2009 after harvest operations had been completed for that crop year. Soil slab monolith samples for the frozen soil slab water run-off portion of the 12-year long-term LHM study were collected in mid-Oct. 2009 after harvest operations were complete. A single soil slab monolith was collected from each of the four replicates for every treatment in the SCM and LHM studies.

In the soil slab monolith collection process, in each treatment plot a small trench was excavated to a depth of approximately $15-20 \mathrm{~cm}$ in a rectangle to expose a $30 \times 40 \mathrm{~cm}$ section of soil. A crosscut hand saw was then used to horizontally cut a 30 by $40 \mathrm{~cm}$ soil cross section slab at an approximate depth of $10-20 \mathrm{~cm}$ (Figure 1 ). Once the soil slab section plus the accompanying crop residues had been severed from the surrounding soil, a plastic plexiglass sheet was inserted into the severed section in order to keep the slab section intact, and to ensure that 
the slab was not fractured during removal. The soil slab section was then wrapped in shipping tape to prevent fracture and breakup during transport to the laboratory, placed in a plastic storage container and then immediately placed in a freezer where they were stored at $-20{ }^{\circ} \mathrm{C}$ until the simulated snowmelt treatment.
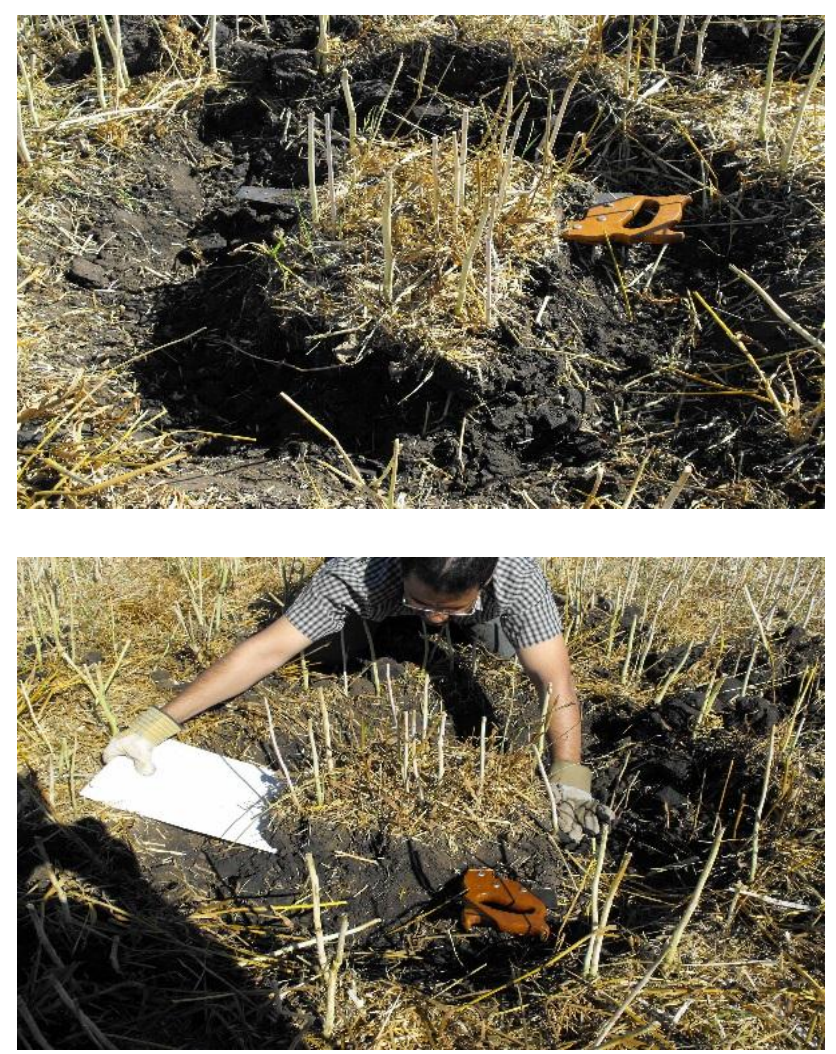

Figure 1. Collection of soil slab monoliths from Dixon three-year solid cattle manure and 12-year long-term liquid hog manure study at Dixon, Saskatchewan

In February of 2009 and 2010, undisturbed unblown snow that had recently (within 48 h) fallen was collected from a field at the Goodale Farm $\left(52^{\circ} 03^{\prime} 36^{\prime \prime} \mathrm{N} 106^{\circ} 30^{\prime} 34^{\prime \prime} \mathrm{W}\right)$ located approximately $20 \mathrm{~km}$ south-east of Saskatoon, SK. The undisturbed snow was collected from the field at approximately 50-100 m distance from the road to minimize any contamination of the snow from foreign roadside debris. For measuring snow melt run-off and leaching over thawing soil, the frozen soil slab monoliths were placed inside insulated plywood boxes designed to slow the rapid thawing of the soil slab so as to mimic snowmelt as it occurs in the spring, but also to allow the added snow cover to infiltrate into the subsurface of the soil and not simply run off the soil surface (Figure 2). Approximately $2 \mathrm{~kg}$ of snow (representing $7.5 \mathrm{~cm}$ of snow cover in a field, equivalent to $1.67 \mathrm{~cm}$ of water), was added to the soil slab monolith section surface. The rear of the insulated plywood boxes was elevated to a position of five degrees to allow leachate and run-off to occur. The boxes were lined with plastic sheets to facilitate snowmelt leachate and run-off collection. Laboratory room temperature was altered for the first $48 \mathrm{~h}$ of the experiment to simulate spring day conditions. Specifically, temperature was altered from $-8{ }^{\circ} \mathrm{C}$ (night), to $0{ }^{\circ} \mathrm{C}$ mid-day, $5{ }^{\circ} \mathrm{C}$ in later portions of the day and back to $-8{ }^{\circ} \mathrm{C}$ at night which allowed more gradual thawing of the soil slab monolith, allowing greater infiltration of the snowmelt water into the soil slab. 

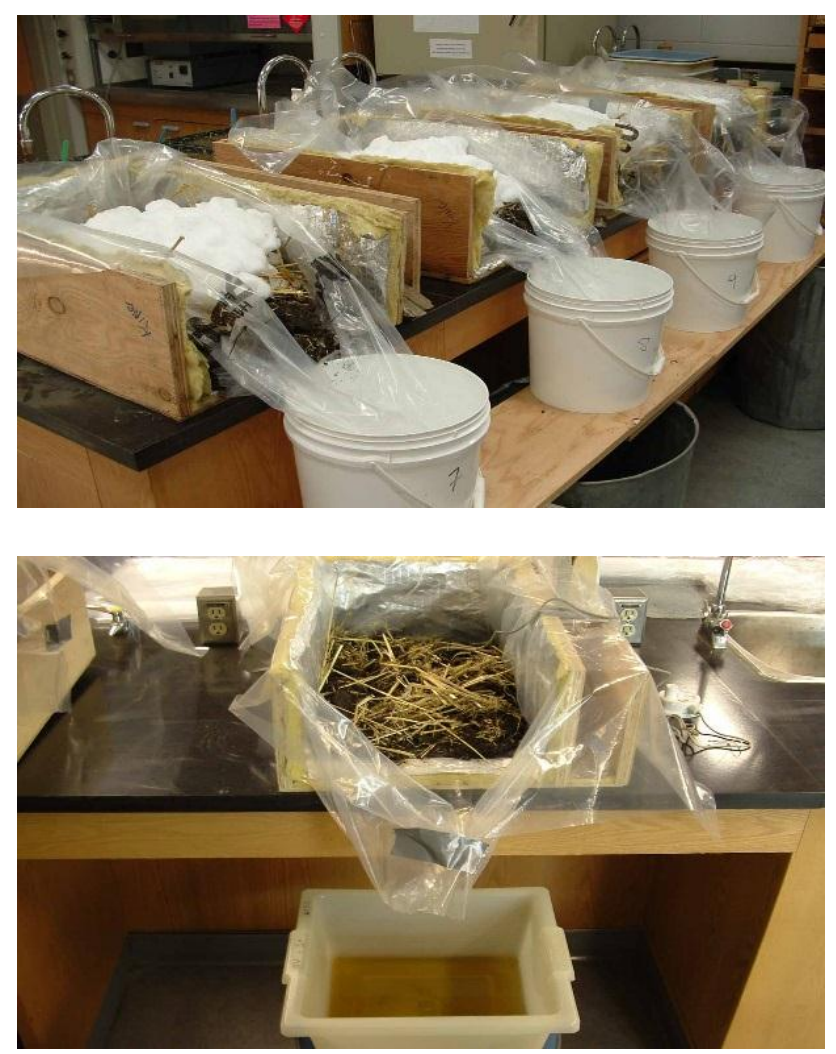

Figure 2. Simulated snowmelt on thawing soil slab monoliths and collection of run-off-leachate

Additionally, soil slab monoliths were used to simulate and measure nutrient movement in surface water run-off passing quickly across frozen soil. This experiment was conducted to simulate a warm Canadian prairie spring day in which snow has melted and water is moving rapidly across a field while the soil surface remains in a predominately frozen or unthawed state. A set of $-20^{\circ} \mathrm{C}$ frozen soil slabs sampled from the treatments obtained in Oct. 2009 were placed in elevated boxes as described above. Two $\mathrm{kg}$ of water at $2{ }^{\circ} \mathrm{C}$ was poured over a 60 -second time period from a plastic bucket directly and rapidly at a distance of $2 \mathrm{~cm}$ from the slab surface starting from the elevated portion of the frozen soil slab surface and water was collected at the lower portion of the elevated box as described previously.

The leachate and run-off from the thawing soil slab monoliths and the frozen soil slabs was collected, the volume collected was measured, recorded and samples immediately frozen and stored at $-20{ }^{\circ} \mathrm{C}$ until the samples were thawed and filtered using Millipore ${ }^{\mathrm{TM}} 45 \mu \mathrm{m}$ glass filters. All of the filtered samples were analyzed for SRP, $\mathrm{NO}_{3}-\mathrm{N}$ and $\mathrm{NH}_{4}-\mathrm{N}$ using a Technicon ${ }^{\odot}$ II automated colorimetry analyzer (American Public Health Association 2005). A sub-sample of collected snow was melted separately, filtered and analyzed to determine the background levels of the above nutrients, which was subtracted from the treatment run-off concentrations.

\subsection{Data Analysis}

Data from both the three-year SCM and 12-year long-term LHM studies were analyzed as a randomized complete block design, replicated four times for all field experiments at the SCM Saskatchewan site for SRP, $\mathrm{NO}_{3}-\mathrm{N}$ and $\mathrm{NH}_{4}-\mathrm{N}$ with two factors for the SCM application: rate of SCM treatment amendment and method of SCM application. The 12 year long-term LHM study was analyzed as a randomized complete block design, replicated four times for all field experiments for SRP, $\mathrm{NO}_{3}-\mathrm{N}$ and $\mathrm{NH}_{4}-\mathrm{N}$ with two factors for the LHM application: rate of LHM treatment amendment and method of LHM application. Data from the SCM and LHM sites were analyzed independently. Sample data was analyzed for normality and equality of variances using the univariate procedure and transformed where necessary. Means separation comparisons for all variables were conducted using the general linear model procedure using a least significant difference (LSD) of $(P \leq 0.10)$ calculated with SAS Proc GLM (SAS version 9.0, 2008). 


\section{Results}

\subsection{Soluble Reactive Phosphorus Export in Snowmelt Water on Thawing Solid Cattle Manure Amended Soil}

In the SCM soil slabs collected in the fall of 2008, the SRP exported in run-off and leachate from snowmelt was observed to be significantly $(P \leq 0.10)$ higher in the broadcast and incorporated and subsurface banded treatments than the $0.02 \mathrm{~kg} \mathrm{P} \mathrm{ha}^{-1}$ exported in the unamended control (Figure 3a). As was observed in the 2008 thawing snow and soil slabs, the SRP exported in the SCM treatments in 2009 was significantly greater than the $0.03 \mathrm{~kg} \mathrm{SRP} \mathrm{ha}^{-1}$ exported in the control treatment (Figure 3b). In 2008 and 2009, the manured treatments were found to be significantly $(P \leq 0.10)$ higher in SRP export than the disturbed-control treatment. Amounts of $\mathrm{P}$ exported in manured treatments ranged from about $0.1 \mathrm{~kg} \mathrm{Pha}^{-1}$ in the broadcast SCM treatment in 2008 to about $0.5 \mathrm{~kg} \mathrm{P} \mathrm{ha}^{-1}$ in the subsurface banded treatment in 2009. The amounts of P removed from the SCM treated soils are 10 times higher than in the non-manured controls. These findings are in agreement with Smith et al. (2011) who reported that SRP concentrations in spring snowmelt water from cattle overwintering sites in east-central Saskatchewan were over $10.0 \mathrm{mg} \mathrm{PO}_{4}-\mathrm{P} \mathrm{L}^{-1}$, which was 20 times greater than the $\mathrm{P}$ concentration in the control basin water run-off $\left(0.47 \mathrm{mg} \mathrm{PO} \mathrm{PO}_{4}^{-}-\mathrm{P} \mathrm{L}^{-1}\right)$. Olsen et al. (2010) has reported greater amounts of $\mathrm{P}$ and $\mathrm{N}$ in water runoff from cattle manured soil after the first year of application in a multi-year study in Alberta, but with reduced $\mathrm{P}$ and $\mathrm{N}$ in runoff in subsequent years. This was not the case in the present study, as the amount of SRP exported increased from 2008 to 2009, but is consistent with a greater amount of P applied in the SCM treatments in 2009 (Table 1) and the higher soil test extractable P in the fall of 2009 (Table 3).

a)

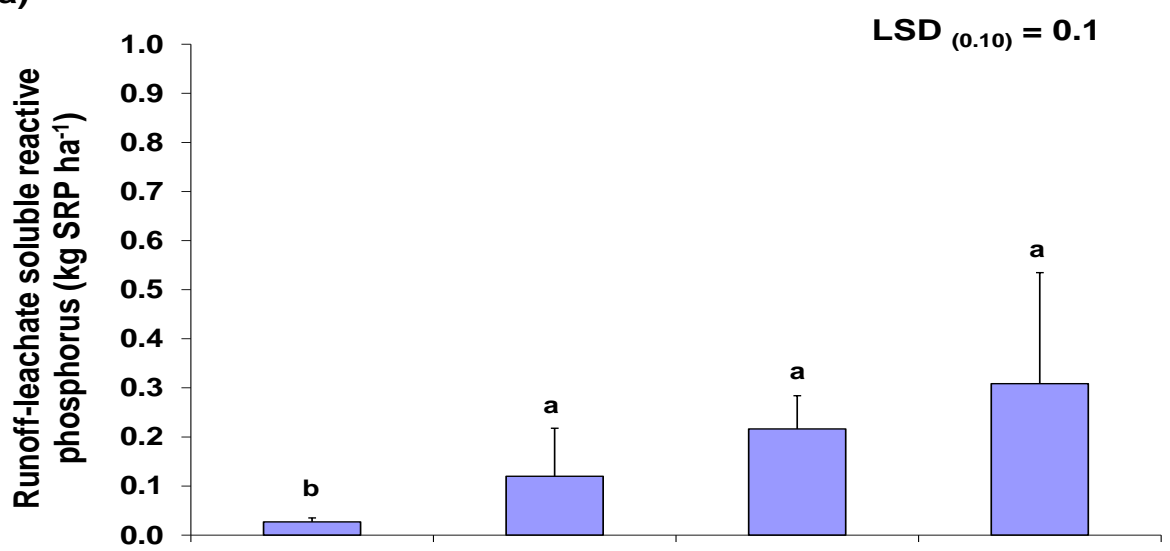

b)

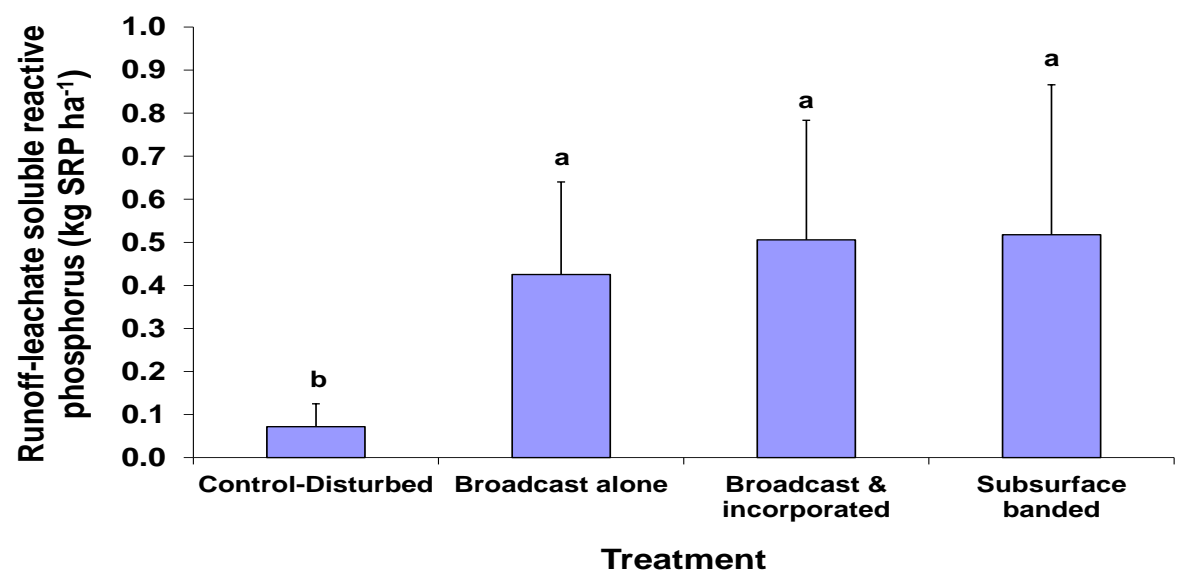

Figure 3. Export of soluble reactive phosphorus $\left(\mathrm{kg} \mathrm{P} \mathrm{ha}^{-1}\right)$ by thawing snow on thawing soil slab monoliths from a three-year solid cattle manure field study collected in a) fall 2008 and b) fall 2009. Means followed by the same letter are not significantly $(P \leq 0.10)$ different. Error bars denote standard deviations of the means 


\subsection{Soluble Reactive Phosphorus Export in Water Moving Rapidly Across the Surface of Frozen Cattle Manure Amended Soil}

In snowmelt conditions of water passing rapidly over frozen soil monoliths obtained from the SCM site in mid-Oct. 2009, the SRP exported in the three manure treatments was significantly $(P \leq 0.10)$ higher than the 0.03 $\mathrm{kg} \mathrm{SRP} \mathrm{ha}{ }^{-1}$ exported in the control treatment (Figure 4). Overall, SRP export in water running rapidly across the surface of SCM treatment frozen soil slabs was approximately $0.15 \mathrm{~kg} \mathrm{SRP} \mathrm{ha}^{-1}$, which is less than one-half of that in the thawing snow and soil. This is expected due to a lower degree of interaction between water and soil when the soil surface is frozen. The longer time duration associated with the snowmelt run-off and leaching on the thawing soil slabs contrasts with the shorter time duration of the simulation of water running across the frozen surface of soil. This difference in time and frozen soil conditions which prevents infiltration of water means a reduced degree of soil-water interaction. It appears that the nature of the thaw and run-off such as thawing versus frozen soils can considerably influence the amount of nutrient ion that may be exported off the field.

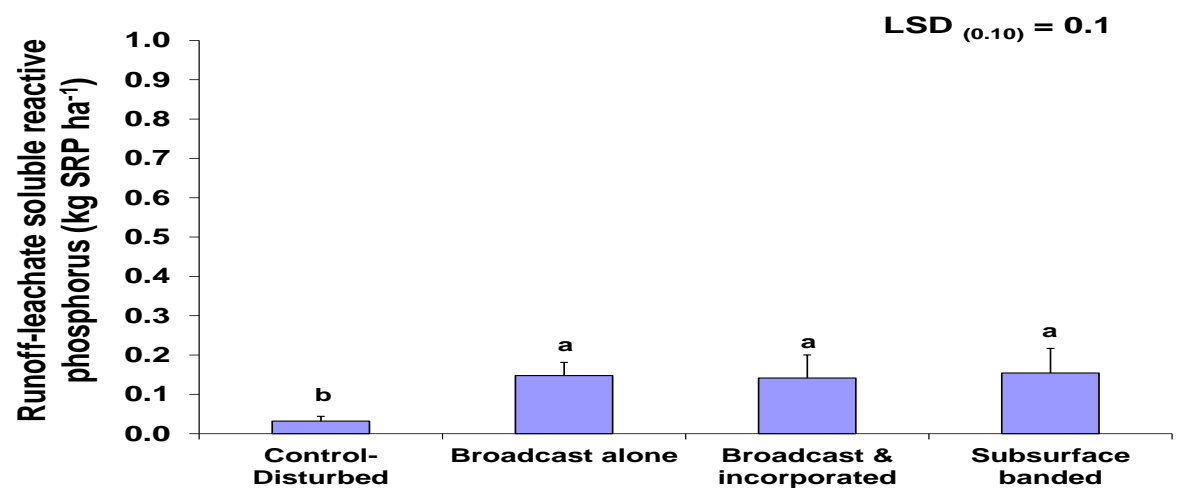

Figure 4. Export of soluble reactive phosphorus $\left(\mathrm{kg} \mathrm{Pha}^{-1}\right)$ in water moving rapidly across the surface of frozen soil slab monoliths collected in fall 2009 from a three-year solid cattle manure field study site. Means followed by

the same letter are not significantly $(\mathrm{P} \leq 0.10)$ different. Error bars denote standard deviations of the means

\subsection{Soluble Reactive Phosphorus Export in Thawing Snow and Soils from Liquid Hog Manure Amended Soil}

As expected, the amounts of SRP exported via run-off and leachate from thawing snow and soil slab monoliths collected from the long-term (12 years of application) LHM field study site was increased with LHM application (Figure 5). The SRP removed in the annual application rate of $148,000 \mathrm{~L} \mathrm{ha}^{-1}$ (Figure 5) of about $0.05 \mathrm{~kg} \mathrm{P} \mathrm{ha}^{-1}$ was significantly $(P \leq 0.10)$ greater than the control-disturbed treatment but was not significantly $(P \leq 0.10)$ different from the other treatments, which themselves were not significantly different from the control treatment. Overall, the LHM SRP exports from 12 years of LHM application are about 10\% of the SCM exports from two years of SCM application (Figure 3a), despite only slightly lower amounts of P added as LHM over 12 years in the $148,000 \mathrm{~L} \mathrm{ha}^{-1}$ rate treatments as added in two years of SCM application at $60 \mathrm{t} \mathrm{ha}^{-1}$. This can be explained in part by crop uptake and removal of the P added in the LHM treatments over the 12 years (Stumborg and Schoenau, 2008). This resulted in a smaller P surplus for the LHM field-study compared to the SCM study and much lower soil test extractable P contents in the soil of the LHM (Table 4) compared to the SCM (Table 3). 


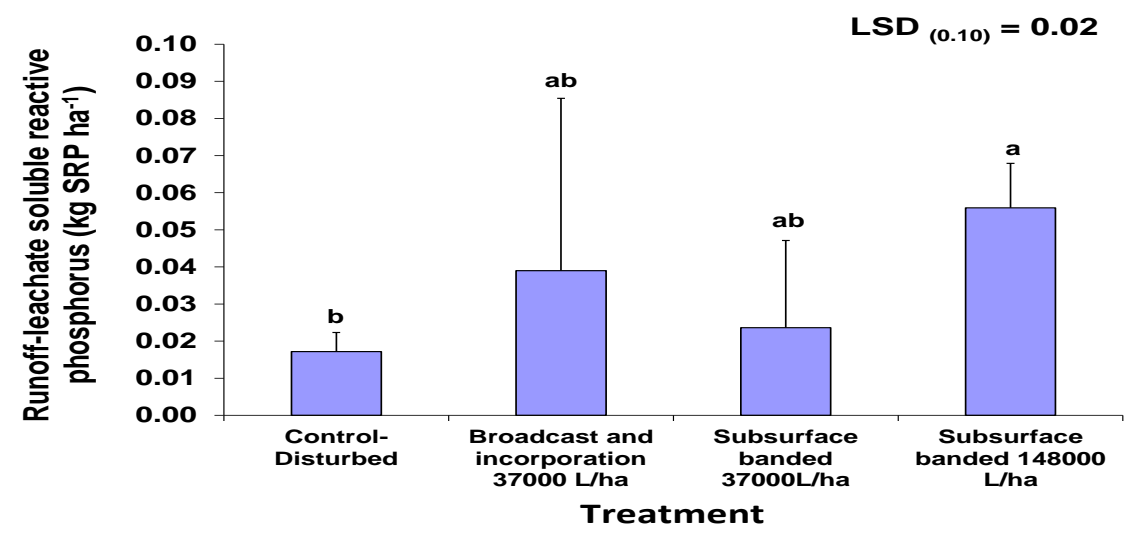

Figure 5. Export of soluble reactive phosphorus $\left(\mathrm{kg} \mathrm{P} \mathrm{ha}^{-1}\right)$ by thawing snow on thawing soil slab monoliths collected in fall 2009 from a 12-year long-term liquid hog manure field study site. Means followed by the same letter are not significantly $(P \leq 0.10)$ different. Error bars denote standard deviations of the means

\subsection{Phosphorus Export in Water Moving Rapidly Across the Surface of Frozen Liquid Hog Manure Amended Soil}

The SRP exported in water moving rapidly across the frozen surface of the LHM soil slabs (Figure 6) was approximately one-tenth of the amount of SRP export in water moving rapidly across the frozen soil surface after two years of manure application at the SCM site.

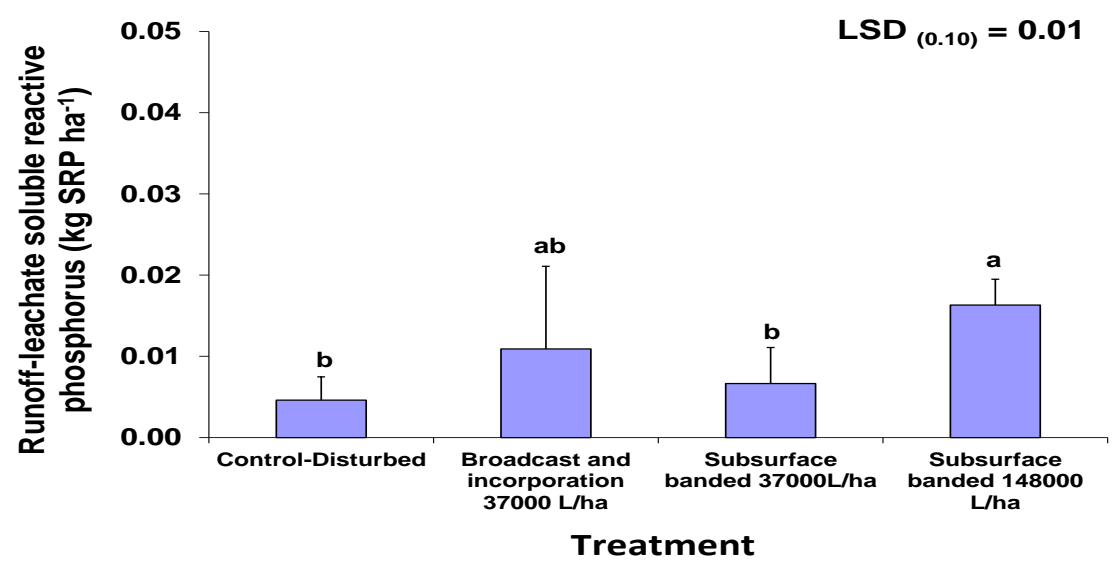

Figure 6. Export of soluble reactive phosphorus $\left(\mathrm{kg} \mathrm{P} \mathrm{ha}^{-1}\right)$ in water moving rapidly across the surface of frozen soil slabs in a fall 2009 12-year long-term liquid hog manure field study site. Means followed by the same letter are not significantly $(P \leq 0.10)$ different. Error bars are standard deviations of the means

This may be explained by the amount of $\mathrm{P}$ added, as the amount of $\mathrm{P}$ added over 12 years of LHM (Table 2) application at the 37,000 $\mathrm{L} \mathrm{ha}^{-1}$ rate was much smaller than the amount of P added in SCM at the $60 \mathrm{t} \mathrm{ha}^{-1} \mathrm{rate}$ over 3 years (Table 1$)$.

The amount of P added over 12 years of LHM (Table 2) application at the 148,000 $\mathrm{L} \mathrm{ha}^{-1}$ rate was four times greater than the amount of $\mathrm{P}$ added at the $37,000 \mathrm{~L} \mathrm{ha}^{-1}$ rate. Soluble reactive $\mathrm{P}$ export was found to be much less than the SRP export in the SCM treatments. The LHM subsurface banded high rate 148,000 $\mathrm{L} \mathrm{ha}^{-1}$ produced a significantly $(P \leq 0.10)$ greater amount of exported SRP in runoff moving across a frozen soil surface, compared to the lower $37,000 \mathrm{~L} \mathrm{ha}^{-1}$ subsurface banded LHM treatment and the control treatment. Of the different manure type (SCM and LHM) and snowmelt (thawing and frozen soil surface) scenarios examined, the rapid flow of water movement across the frozen surface of LHM amended soil resulted in the lowest SRP export from the soil, around $0.01 \mathrm{~kg} \mathrm{Pha}^{-1}$.

\subsection{Dissolved Nitrate-nitrogen Export in Snowmelt Water on Thawing Solid Cattle Manure Amended Soil}

In the SCM thawing soil slabs from fall of 2008, the amounts of dissolved $\mathrm{NO}_{3}-\mathrm{N}$ in run-off and leachate 
snowmelt derived water were similar among manured treatments $\left(\sim 0.4 \mathrm{~kg} \mathrm{NO}_{3}-\mathrm{N} \mathrm{ha}{ }^{-1}\right)$ and were not significantly different $(P \leq 0.10)$ from the control-disturbed treatment (Figure 7a). Dissolved $\mathrm{NO}_{3}-\mathrm{N}$ concentrations for fall 2008 are reported in Appendix Table B.7. This agrees with observations by Smith et al. (2011), where little $\mathrm{NO}_{3}-\mathrm{N}$ in run-off water was observed from winter snowmelt after the first year of manure application in a winter-feeding field located in east-central Saskatchewan. Export of dissolved $\mathrm{NO}_{3}-\mathrm{N}$ in the 2009 run-off and leachate was also similar among manured treatments $\left(\sim 2.0-3.0 \mathrm{~kg} \mathrm{NO}_{3}-\mathrm{N} \mathrm{ha}^{-1}\right)$ and were not significantly different $(P \leq 0.10)$ from the control-disturbed treatment (Figure $7 \mathrm{~b})$.
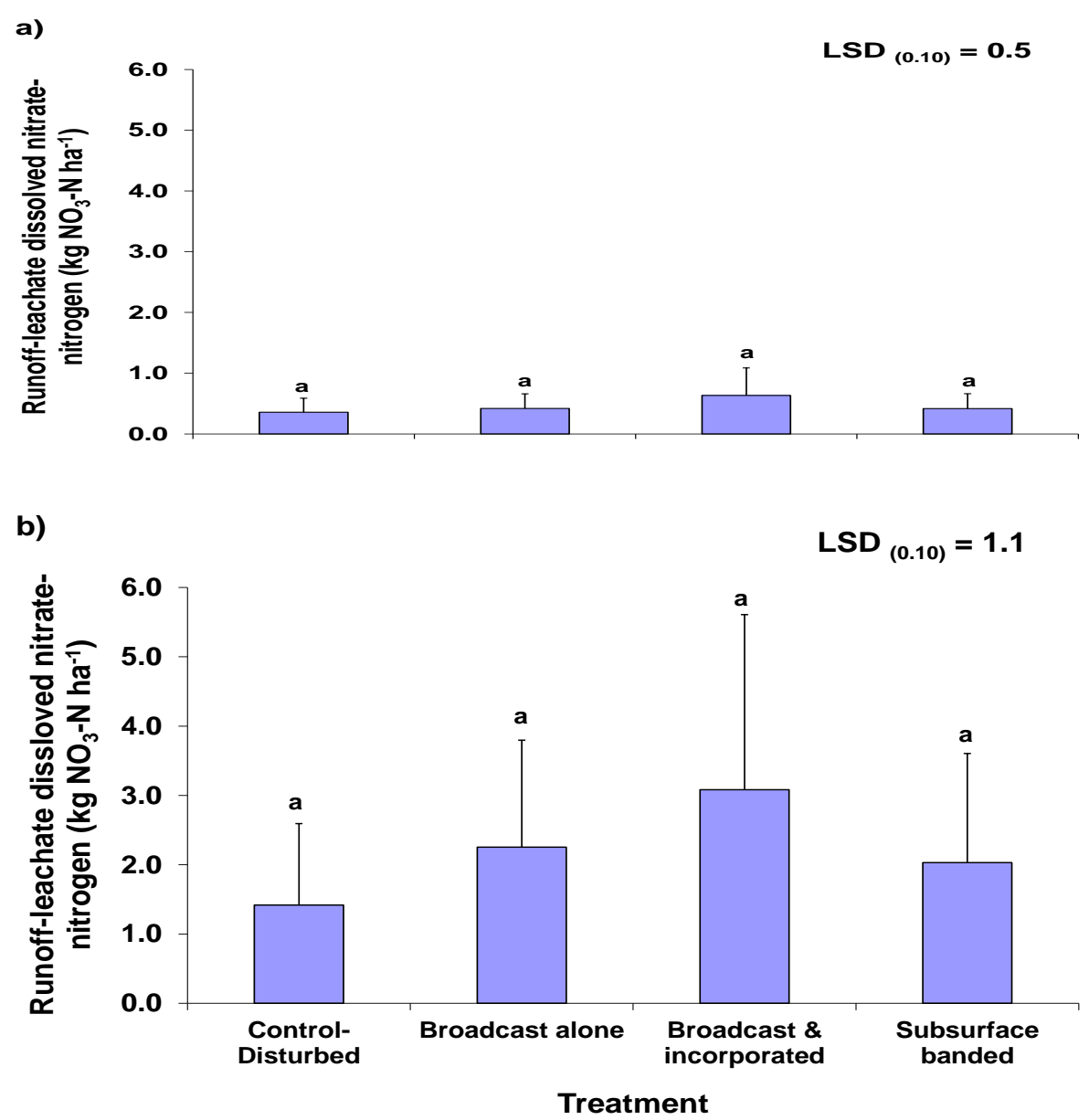

Figure 7. Export of dissolved nitrate-nitrogen $\left(\mathrm{kg} \mathrm{NO}_{3}-\mathrm{N} \mathrm{ha}^{-1}\right)$ by thawing snow on thawing soil slab monoliths from a three-year solid cattle manure field study collected in a) fall 2008 and b) fall 2009. Means followed by the same letter are not significantly $(P \leq 0.10)$ different. Error bars denote standard deviations of the means

3.6 Dissolved Nitrate-nitrogen Export in Water Moving Rapidly across the Surface of Frozen Solid Cattle Manure Amended Soil

Dissolved $\mathrm{NO}_{3}-\mathrm{N}$ removal in run-off from water moving rapidly across frozen soil slab monoliths in the SCM broadcast and incorporated treatment was significantly $(P \leq 0.10)$ higher than the control treatment (Figure 8). The amount of nitrate removed was about half of the $\mathrm{NO}_{3}-\mathrm{N}$ removed via snowmelt run-off and leachate in the 2008 thawing snow and soil slabs, and it was $10 \%$ of the dissolved $\mathrm{NO}_{3}-\mathrm{N}$ removed in the 2009 thawing snow and soil slabs (Figure 7b). 


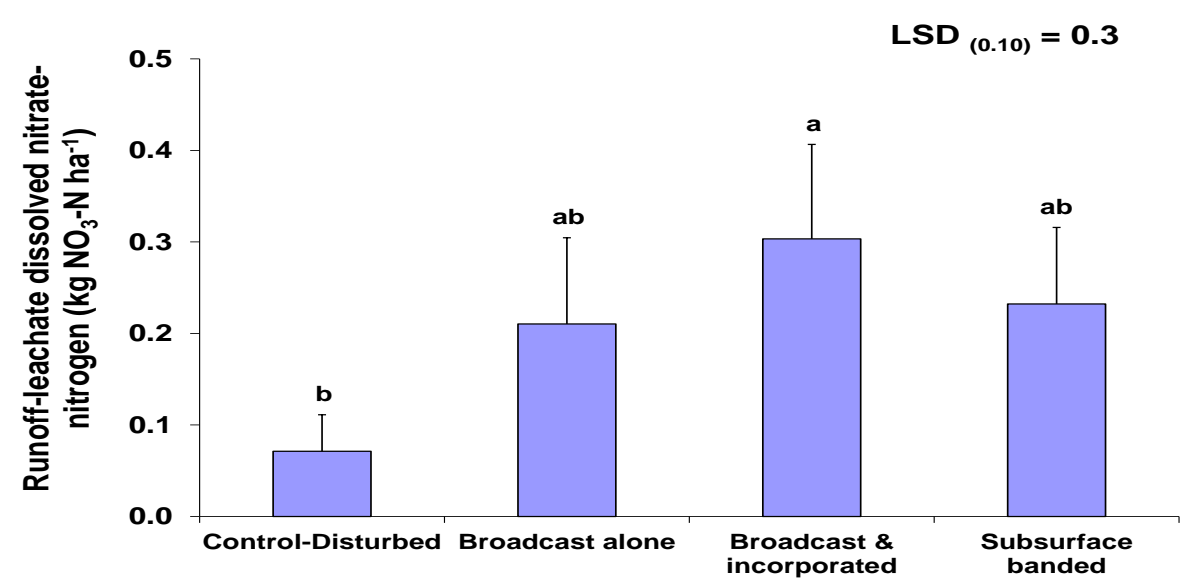

Figure 8. Export of dissolved nitrate-nitrogen $\left(\mathrm{kg} \mathrm{NO}_{3}-\mathrm{N} \mathrm{ha}^{-1}\right)$ in water moving rapidly across the surface of frozen soil slab monoliths collected in fall 2009 from a three-year solid cattle manure field study site. Means followed by the same letter are not significantly $(P \leq 0.10)$ different. Error bars denote standard deviations of the means

\subsection{Dissolved Nitrate-nitrogen Export in Snowmelt Water on Thawing Liquid Hog Manure Amended Soil}

There were no significant $(P \leq 0.10)$ differences in dissolved $\mathrm{NO}_{3}-\mathrm{N}$ export in water from thawing snow and soil slab monoliths collected in fall of 2009 among the three treatments and the non-manured control (Figure 9).

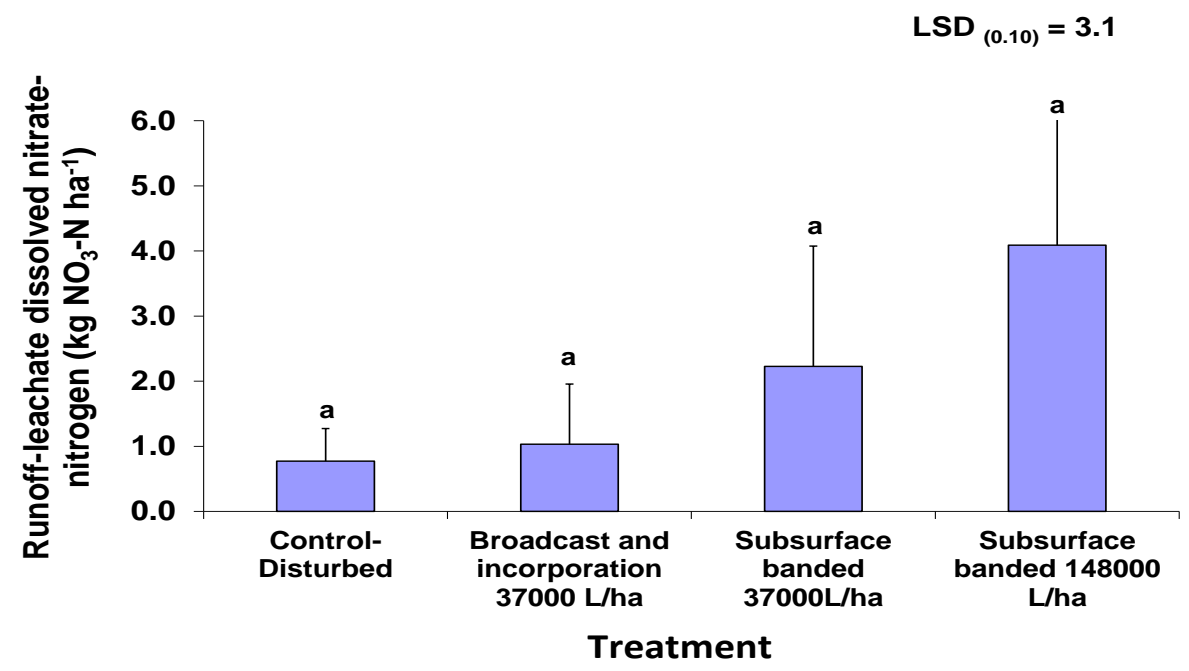

Figure 9. Export of dissolved nitrate-nitrogen $\left(\mathrm{kg} \mathrm{NO}_{3}-\mathrm{N} \mathrm{ha}^{-1}\right)$ by thawing snow on thawing soil slabs collected in fall 2009 from a 12-year long-term liquid hog manure field study site. Means followed by the same letter are not significantly $(P \leq 0.10)$ different. Error bars denote standard deviations of the means

For the low rate of application, the subsurface banding tended to result in greater export than broadcast and incorporate, and export increased with rate. The amounts removed (about 1-4 $\mathrm{kg} \mathrm{NO}_{3}-\mathrm{N} \mathrm{ha}^{-1}$ ) were similar to the amounts of nitrate removed in the SCM fall 2009 soils, despite lower fall soil nitrate contents in the SCM amended soils compared to the LHM amended soils. The reason for this is not known, but might reflect a greater interaction of snowmelt water with the soil in the SCM amended soil compared to the LHM amended soil.

3.8 Dissolved Nitrate-nitrogen in Water Moving Rapidly Across the Surface of Frozen Liquid Hog Manure Amended Soil

Dissolved $\mathrm{NO}_{3}-\mathrm{N}$ export in water passing over frozen soil slab monoliths was not significantly different among the LHM treatments (Figure 10). As for phosphate, amounts of $\mathrm{NO}_{3}-\mathrm{N}$ removed in water passing over the frozen surface were considerably less than for snow melting on thawing soil. Soil texture, water infiltration rates and 
redistribution of crop residues via tillage operations can all have an effect on the amount of $\mathrm{NO}_{3}-\mathrm{N}$ that is retained near the soil surface (Stumborg et al., 2007). The subsurface flow of snowmelt water through thawing soil often results in much greater $\mathrm{NO}_{3}-\mathrm{N}$ removal (Li et al., 2011).

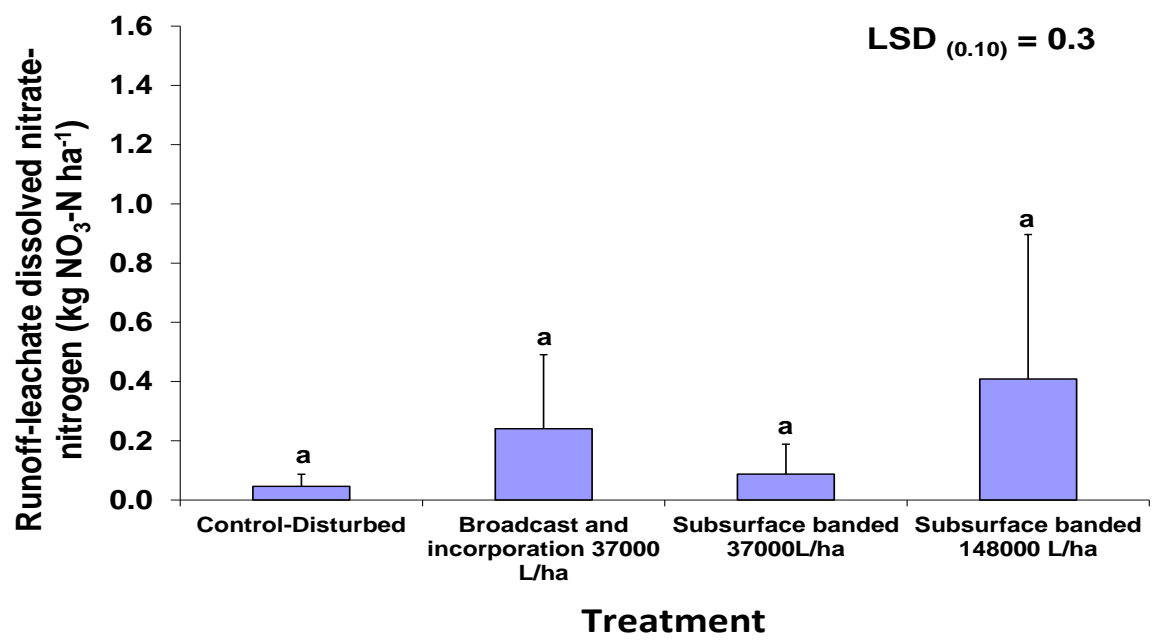

Figure 10. Export of dissolved nitrate-nitrogen $\left(\mathrm{kg} \mathrm{NO}_{3}-\mathrm{N} \mathrm{ha}^{-1}\right)$ in water moving rapidly across the surface of frozen soil slabs in a fall 2009 12-year long-term liquid hog manure field study site. Means followed by the same letter are not significantly $(\mathrm{P} \leq 0.10)$ different. Error bars are standard deviations of the means

\subsection{Dissolved Ammonium-nitrogen Export in Snowmelt Water on Thawing Solid Cattle Manure Amended Soil}

The dissolved $\mathrm{NH}_{4}-\mathrm{N}$ export was not significantly $(\mathrm{P} \leq 0.10)$ different between the disturbed-control treatment, broadcast alone, broadcast and incorporated and subsurface banded SCM treatments (Figure 11). Strong adsorption to soil particles could explain the low amount of $\mathrm{NH}_{4}-\mathrm{N}$ extracted by water passing across and through the soil. Manure $\mathrm{NH}_{4}-\mathrm{N}$ is readily adsorbed and held on the soil cation-exchange sites and is not easily extracted from the soil with water. In this study, the $\mathrm{NH}_{4}-\mathrm{N}$ released from manure could also have been rapidly utilized by plants during the growing season and/or nitrified thus leaving little residual $\mathrm{NH}_{4}-\mathrm{N}$ (Stumborg et al., 2007). In agreement with this, soil $\mathrm{NH}_{4}-\mathrm{N}$ contents in the fall were low (Table 3), and are consistent with low (around $0.02 \mathrm{~kg} \mathrm{NH}_{4}-\mathrm{N} \mathrm{ha}^{-1}$ ) amounts of $\mathrm{NH}_{4}-\mathrm{N}$ exported in the run-off and leachate water collected from the melting snow on the slabs. The amounts of $\mathrm{NH}_{4}-\mathrm{N}$ exported are about 50 times lower than the amounts of $\mathrm{NO}_{3}-\mathrm{N}$ (Figure 10).

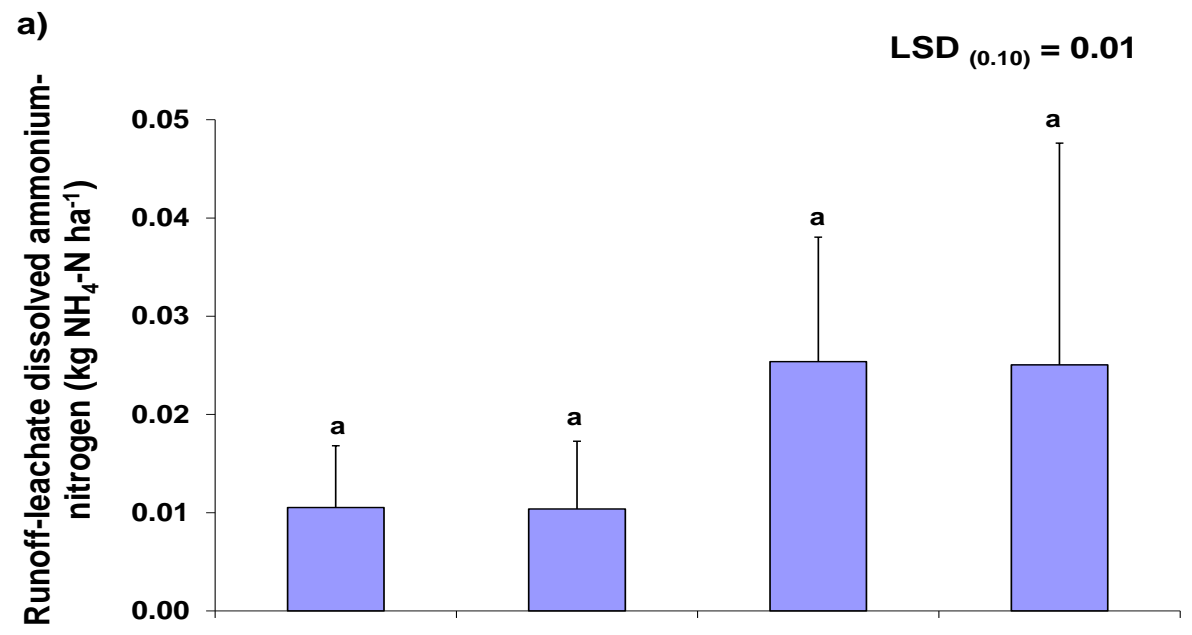




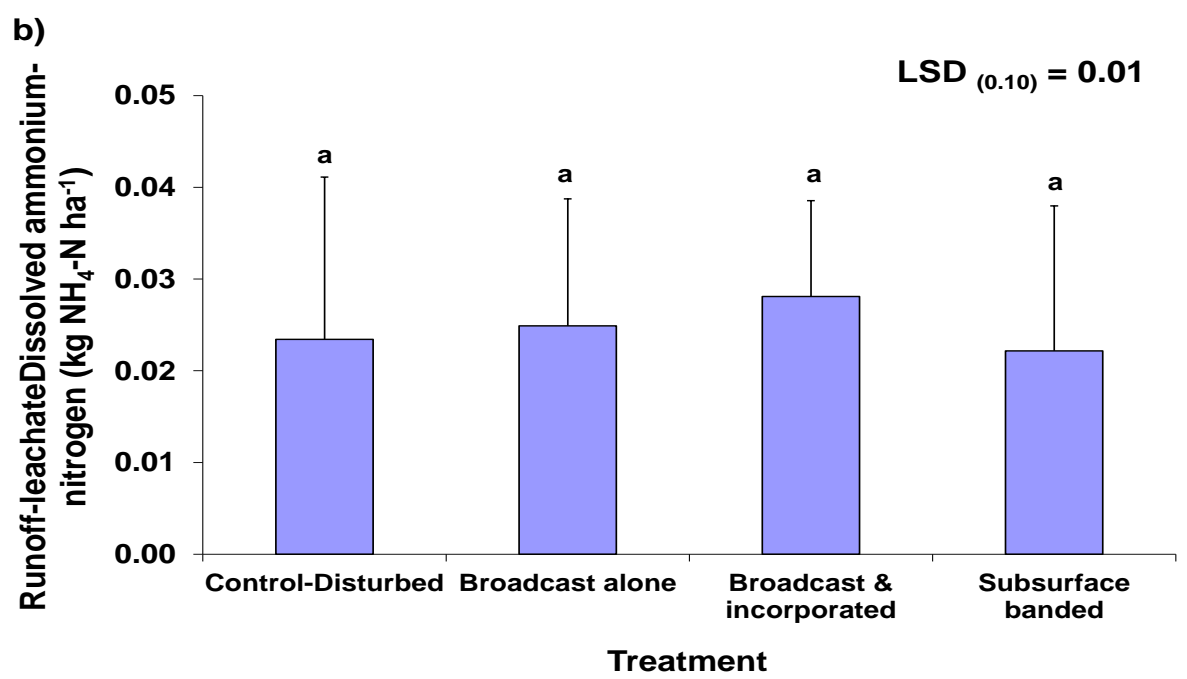

Figure 11. Export of dissolved ammonium-nitrogen $\left(\mathrm{kg} \mathrm{NH}_{4}-\mathrm{N}^{-1}\right)$ by thawing snow on thawing soil slab monoliths from a three-year solid cattle manure field study collected in a) fall 2008 and b) fall 2009. Means followed by the same letter are not significantly $(P \leq 0.10)$ different. Error bars denote standard deviations of the means

\subsection{Dissolved Ammonium-nitrogen Export in Water Moving Rapidly across the Surface of Frozen Solid Cattle Manure Amended Soil}

The manure treatments and nature of run-off had relatively little effect on $\mathrm{NH}_{4}-\mathrm{N}$ export in water running rapidly

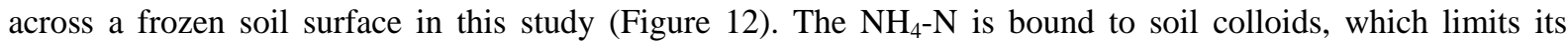
interaction and release to water passing through. The frozen condition of the surface soil would further limit interaction. However, others have noted that $\mathrm{NH}_{4}-\mathrm{N}$ export can still occur depending on ice content in the pores (Steenhuis et al., 1981).

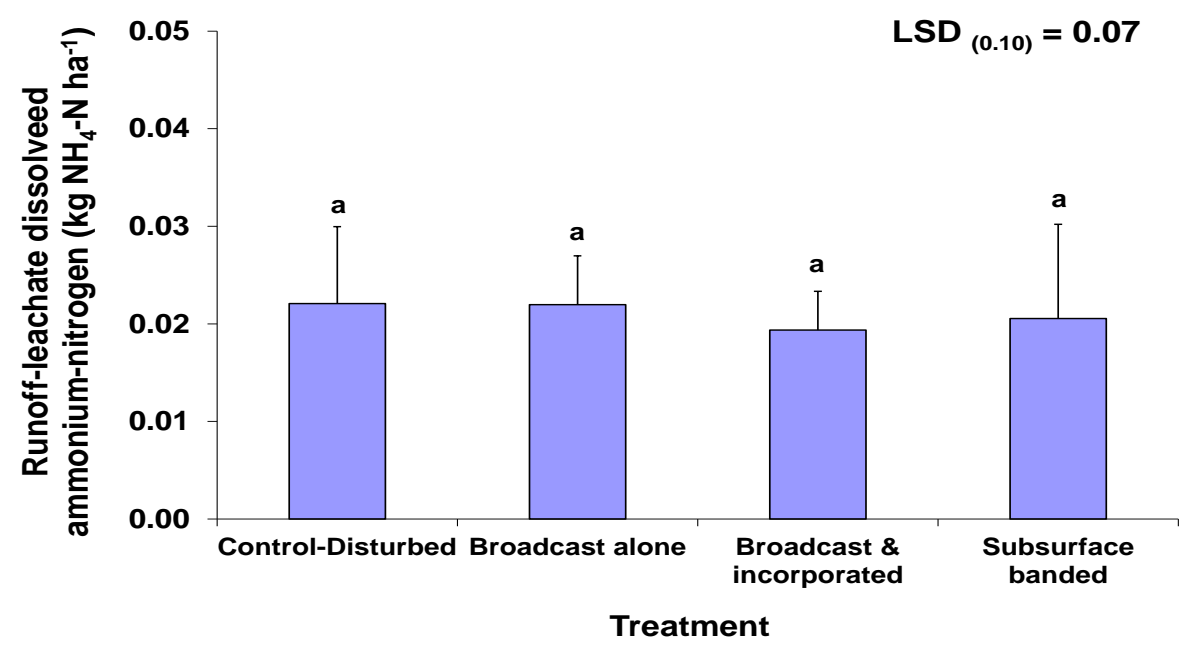

Figure 12. Export of dissolved ammonium-nitrogen $\left(\mathrm{kg} \mathrm{NH}_{4}-\mathrm{N} \mathrm{ha}^{-1}\right)$ in water moving rapidly across the surface of frozen soil slab monoliths collected in fall 2009 from a three-year solid cattle manure field study site. Means followed by the same letter are not significantly $(P \leq 0.10)$ different. Error bars denote standard deviations of the means

\subsection{Dissolved Ammonium-nitrogen Export in Snowmelt Water on Thawing Liquid Hog Manure Amended Soil}

There were no significant differences in $\mathrm{NH}_{4}-\mathrm{N}$ export in water among the three LHM treatments at the 12-year long-term site (Figure 13). With similar clay content at both the SCM and LHM field sites (they are located adjacent to each other), cation adsorption would be similar. More $\mathrm{NH}_{4}-\mathrm{N}$ was added with the LHM compared to 
the SCM, however run-off and leachate $\mathrm{NH}_{4}-\mathrm{N}$ concentrations were similar, which could be attributed to utilization of the $\mathrm{LHM} \mathrm{NH} \mathrm{NH}_{4} \mathrm{~N}$ by the crops along with nitrification from the time of application in spring to sampling time in the fall.

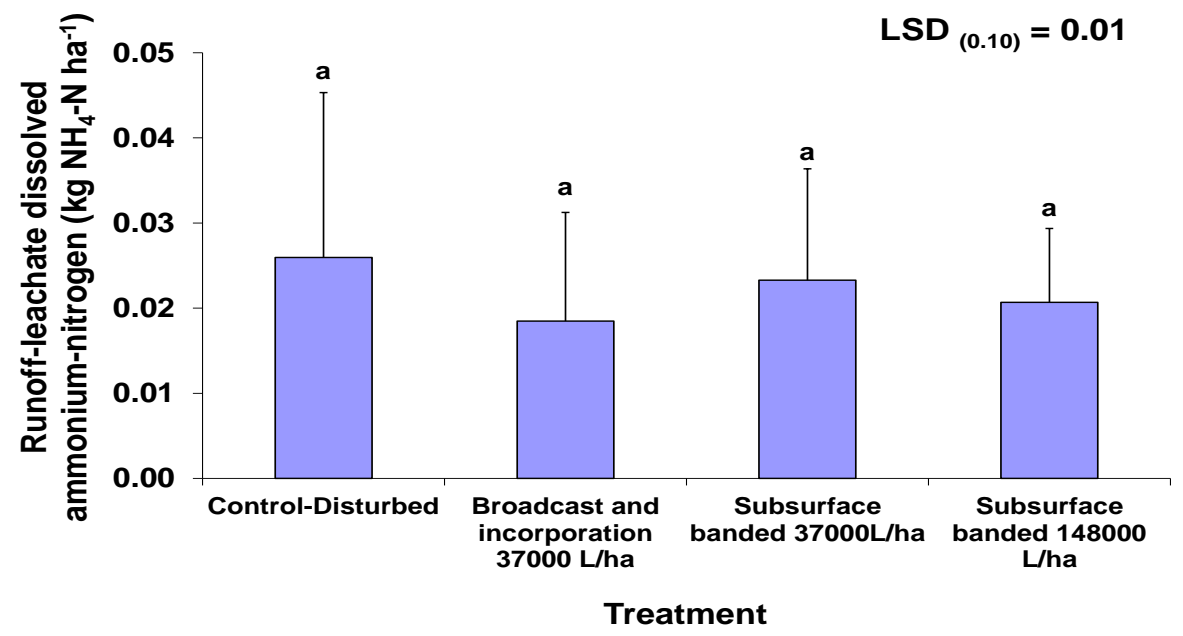

Figure 13. Export of dissolved ammonium-nitrogen $\left(\mathrm{kg} \mathrm{NH}_{4}-\mathrm{N} \mathrm{ha}^{-1}\right)$ by thawing snow on thawing soil slabs collected in fall 2009 from a 12-year long-term liquid hog manure field study site. Means followed by the same letter are not significantly $(P \leq 0.10)$ different. Error bars denote standard deviations of the means

\subsection{Dissolved Ammonium-nitrogen in Water Moving Rapidly across the Surface of Frozen Soils from Liquid Hog Manure Amended Soil}

Similar to the results from the SCM treatments, the amount of $\mathrm{NH}_{4}-\mathrm{N}$ exported in all three of the LHM treatments for water running across frozen soils was similar and not significantly $(P \leq 0.10)$ different from the control treatment (Figure 14), and also similar to the amount of $\mathrm{NH}_{4}-\mathrm{N}$ collected in run-off and leachate from thawing snow and soil slabs (Figure 13). The amount of $\mathrm{NH}_{4}-\mathrm{N}$ collected was similar between the three LHM treatments at $\sim 0.03 \mathrm{~kg} \mathrm{ha}^{-1}$ and not significantly different from the control-disturbed treatment. The observed lack of differences in $\mathrm{NH}_{4}-\mathrm{N}$ export between the three LHM treatments and the control treatment could be due to the rapid conversion of $\mathrm{NH}_{4}-\mathrm{N}$ to $\mathrm{NO}_{3}-\mathrm{N}$ in the nitrification process after each annual spring application of LHM. Combined with plant uptake of the $\mathrm{N}$ contained in the LHM, there was little accumulated $\mathrm{NH}_{4}-\mathrm{N}$ in the soil. This would have left very low amounts on the frozen soil surface of the soil slabs available for export.

The lack of treatment effects of $\mathrm{LHM}$ on $\mathrm{NH}_{4}-\mathrm{N}$ export is similar to the lack of treatment effects for SCM. There was less $\mathrm{NH}_{4}-\mathrm{N}$ added in the SCM compared to the $\mathrm{NH}_{4}-\mathrm{N}$ added in the LHM, thus very low amounts remaining on the soil surface available for export off fall season extracted soil slabs.

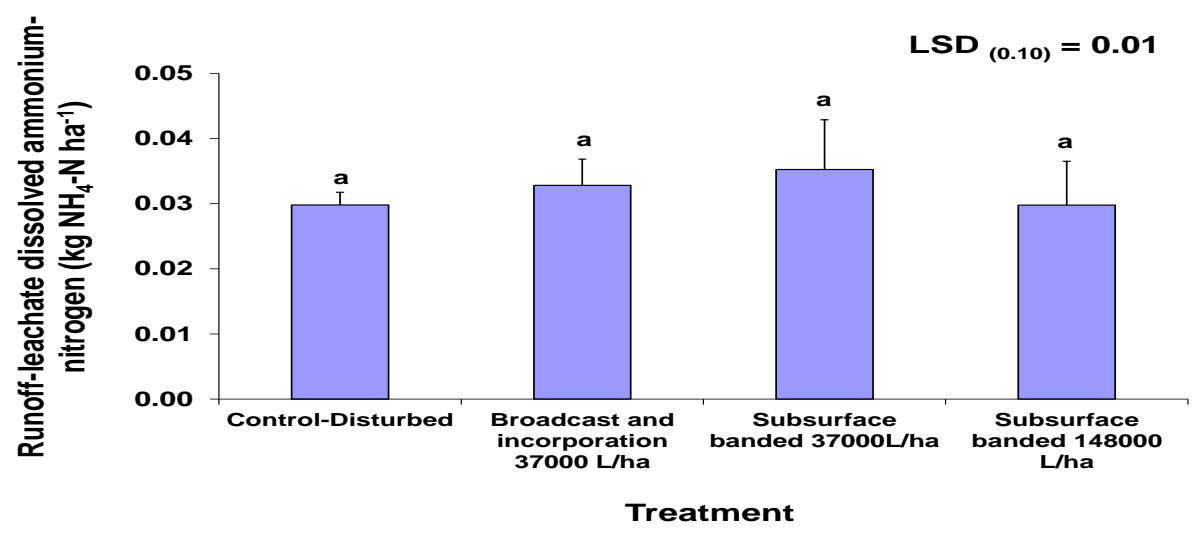

Figure 14. Export of dissolved ammonium-nitrogen $\left(\mathrm{kg} \mathrm{NH}_{4}-\mathrm{N} \mathrm{ha}^{-1}\right)$ in water moving rapidly across the surface of frozen soil slabs in a fall 2009 12-year long-term liquid hog manure field study site. Means followed by the same letter are not significantly $(P \leq 0.10)$ different. Error bars are standard deviations of the means 


\section{Discussion}

\subsection{Soil Reactive Phosphorus}

Immobilization of P in SCM in organic forms and slow mineralization (Stumborg and Schoenau, 2008) could explain why overall SRP export was less than $1 \mathrm{~kg} \mathrm{SRP} \mathrm{ha}^{-1}$ for all three SCM application methods. As well, the brief soil-water interaction time may not have been sufficient to mobilize much P. Converse et al. (1976) and Kongoli and Bland (2002) have noted that removal of nutrients with run-off water after winter applications of manure varies with the nature of the manure. Specifically solid animal manures containing greater amounts of bedding and straw, such as the manure used in this study, can serve as a mulch platform that limits or reduces the amounts of nutrients that can be removed by snowmelt run-off water. The less than $1 \mathrm{~kg} \mathrm{SRP} \mathrm{ha}^{-1}$ export for all three SCM application methods is negligible compared to the $150 \mathrm{~kg} \mathrm{P} \mathrm{ha}^{-1}$ added in the broadcast alone, broadcast and incorporated and subsurface banded, respectively, SCM treatments in 2008. This could be accounted for by the low solubility of P in SCM and sorption to soil constituents, leading to its decreased mobility (Sharpley and Moyer, 2000). If the amount of P applied is greater than the P sorption capacity of a soil and exceeds the ability of plants to take up available supplies of $\mathrm{P}$ then more $\mathrm{P}$ is predicted to be exported by water (Brye et al., 2002), especially if there are preferential conduit modes of transport, which could explain the greater amount of SRP transported in the subsurface banded SCM treatment. The placement of SCM in a concentrated manure band could potentially overload soil mineral and organic adsorption sites which, combined with the deep horizontal banding $(10-13 \mathrm{~cm})$, creates more opportunity for preferential flow movement.

The P in the LHM would have had more time to react with the soil (12 yrs application period) compared to the shorter application period in the SCM treatments (3 yrs). Campbell et al. (1984) has described how the P concentration in the soil solution is typically low and it is known that $\mathrm{P}$ added as fertilizer can transform into insoluble forms over time, which can retard the availability and movement of $\mathrm{P}$ in the soil solution. Conversion of manure P into less soluble forms may also be occurring in the LHM amended soils over the 12 years of application. The amount of P added in the LHM (Table 2) in Oct. 2008 and Oct. 2009 was quite low compared to the $\mathrm{P}$ added in the SCM (Table 1).

Water soluble $\mathrm{P}$ in manure was reported by Kumaragamage et al. (2011) to be $3.4 \mathrm{~kg} \mathrm{t}^{-1}$ in LHM compared to 0.8 $\mathrm{kg} \mathrm{t}^{-1}$ in SCM. A greater solubility of P in LHM would be expected to result in greater amounts of exportable SRP in runoff and/or leachate from LHM amended soil compared to SCM amended per unit of P added in fresh manure. However, crop uptake and removal of labile, readily available P added over the years in the LHM treatments, low amount of P added with the LHM, along with conversion to less soluble forms once in the soil would mask any effect in the current study.

\subsection{Soil Nitrate-Nitrogen}

Smith et al. (2011) reported average $\mathrm{NO}_{3}-\mathrm{N}$ concentrations in water samples from cattle overwintering sites of $0.25 \mathrm{mg} \mathrm{NO}{ }_{3}-\mathrm{N} \mathrm{L}^{-1}$ compared to $0.19 \mathrm{mg} \mathrm{NO}_{3}-\mathrm{N} \mathrm{L}^{-1}$ in control sites. The microbial conversion of organic $\mathrm{N}$ and $\mathrm{NH}_{4}-\mathrm{N}$ contained in the manure to $\mathrm{NO}_{3}-\mathrm{N}$ can be slowed by cold temperatures (Stark and Firestone, 1996), and the SCM in this study contained relatively little inorganic $\mathrm{N}$. Additionally, most of the inorganic $\mathrm{N}$ would have been utilized by the crop in the first year after application. Moreover, the availability of N added in SCM can be very low due to cattle pen bedding material containing straw and/or wood chips, which can have a high C:N ratio, subsequently limiting mineralization and release of inorganic N (Schoenau and Davis, 2006).

\subsection{Soil Ammonium-Nitrogen}

As noted previously, there was very little $\mathrm{NH}_{4}-\mathrm{N}$ added with the SCM, which could also account for the small amount of run-off and leachate $\mathrm{NH}_{4}-\mathrm{N}$. In $2009, \mathrm{NH}_{4}-\mathrm{N}$ exports were not enhanced in manure treatments compared to the control treatment. Infiltration of the soil micropores by water from snowmelt can be prevented if ice content is blocking the pore system (Ginting et al., 1998; Zuzel and Pikul, 1987). Given the low $\mathrm{NH}_{4}-\mathrm{N}$ content in soils receiving SCM as a consequence of plant uptake and rapid nitrification, and the retention by adsorption to clays and $\mathrm{OM}$, it is not surprising that the manure treatment had minimal influence on $\mathrm{NH}_{4}-\mathrm{N}$ export (Figure 12), and there was little difference in export on thawing and frozen soils.

The observed lack of difference among LHM treatments may be attributed to the rapid conversion of $\mathrm{NH}_{4}-\mathrm{N}$ to $\mathrm{NO}_{3}-\mathrm{N}$ in the nitrification process following manure application and over the subsequent growing seasons, leaving little $\mathrm{N}$ accumulated in the soil as $\mathrm{NH}_{4}-\mathrm{N}$ by the time of slab removal after harvest in the fall. Also, any residual removal of $\mathrm{NH}_{4}-\mathrm{N}$ by water could be reduced due to retention of $\mathrm{NH}_{4}-\mathrm{N}$ on soil cation exchange sites.

\subsection{Future Study Directions}

It should be noted that this study was conducted on extracted soil slabs measuring $30 \mathrm{~cm} \mathrm{X} 40 \mathrm{~cm}$, which 
represents a small portion of a typical cultivated field, thus there is a margin of error due to the small size of the soil slabs being examined. The study was conducted on a level landscape to eliminate the landscape factor of upper shoulder and lower backslope and footslope positions that can be encountered in a typical Saskatchewan landscape. These types of landscape positions would have an effect on study results if this study was replicated by subsurface banding SCM and LHM utilizing landscape formations as a factor. The nature of spring snowmelt runoff, direction of runoff and collection of water on a field would be affected by landscape position and would be a factor to examine in future studies. This study was conducted on a dryland type of cropping system and conducting this study under irrigated conditions would be a potential future direction to further study $\mathrm{P}$ and $\mathrm{N}$ nutrient movement off a field site. Additionally, examining $\mathrm{P}$ and $\mathrm{N}$ export and movement under different types of crops in an irrigated cropping system would also provide further information on nutrient movement in animal manure amended fields.

\section{Conclusions}

The novel methodology that was developed for collecting intact soil slab monoliths from replicated field plots and the development of a technique for simulating melting snow conditions and run-off under two common early spring scenarios has allowed new information to be collected on $\mathrm{P}$ and $\mathrm{N}$ export in snowmelt runoff from fields that have received annual applications of subsurface banded SCM and LHM. The addition of SCM using broadcast alone, broadcast and incorporated and subsurface banding techniques significantly increased SRP export in thawing snow and soil slab monoliths. However, there was no significant $(P \leq 0.10)$ effect of SCM placement method on SRP export in snowmelt run-off and leachate in the soil slabs obtained from the SCM treated plots. This suggests that incorporation of manure or subsurface banding may not be effective in reducing transport. While in-soil placement may reduce manure contact with water during spring melt, it may also enhance the process of manure decomposition and production of SRP as well as provide channels for preferential flow of water. The addition of SCM using all three placement methodologies significantly increased SRP export in run-off collected from water flowing rapidly across the frozen surface of a soil slab. However, the amounts exported by water running across frozen soil were about one half of that exported from snowmelt running off and percolating through thawing soil. Compared to three years of SCM application, applying LHM for 12-years resulted in smaller amounts (about ten times less) of SRP exported in water from soil slab monoliths. This may be explained by crop removal and lower manure P input over the duration of the 12-year long-term LHM study. Reduction in the solubility of the $\mathrm{P}$ with aging could also be a factor. Chemical and spectroscopic assessments of phosphorus species present in the soils would help confirm this aspect.

There was no significant effect of manure application rate or method on $\mathrm{NO}_{3}-\mathrm{N}$ export, except for the broadcast and incorporate SCM treatment which had higher $\mathrm{NO}_{3}-\mathrm{N}$ export in water flowing across the frozen soil surface compared to the unamended control. Overall greater variability was encountered in $\mathrm{NO}_{3}-\mathrm{N}$ export compared to SRP. Similar to phosphate export, the $\mathrm{NO}_{3}-\mathrm{N}$ export was lower in water running across frozen soil surfaces compared to snowmelt occurring on thawing soils. Interestingly, $\mathrm{NO}_{3}-\mathrm{N}$ export was similar between $\mathrm{SCM}$ and LHM amended soils, despite the LHM soils having higher $\mathrm{NO}_{3}-\mathrm{N}$ content. There was a trend for the high LHM application rate which caused accumulation of $\mathrm{NO}_{3}-\mathrm{N}$ in the soil to have the highest $\mathrm{NO}_{3}-\mathrm{N}$ export in snowmelt water. Manure treatment had no significant $(P \leq 0.10)$ effect on $\mathrm{NH}_{4}-\mathrm{N}$ export in the soils, regardless of type of applied animal manure. This may be attributed to the predominance of $\mathrm{NO}_{3}-\mathrm{N}$ over $\mathrm{NH}_{4}-\mathrm{N}$, likely due to rapid nitrification of the $\mathrm{NH}_{4}-\mathrm{N}$, especially after several years of manure application. Nitrification, $\mathrm{N}$ uptake by the crop, and adsorption of $\mathrm{NH}_{4}-\mathrm{N}$ to soil cation exchange sites could explain the observed small amounts of $\mathrm{NH}_{4}-\mathrm{N}$ removed by water in the manure treatments.

\section{Acknowledgements}

The authors would like to thank the Saskatchewan Agriculture Development Fund for funding for this study.

\section{References}

American Public Health Association. (2005). Standards methods for the examination of water and wastewater, $21^{\text {st }}$ ed., Method 4500-P E. www.standardmethods.org/ Accessed July 23, 2012.

Baker, J. L., \& Laflen, J. M. (1983). Runoff losses of nutrients and soil from ground fall-fertilized after soybean harvest. Trans. ASAE, 26, 1122-1127. https://doi.org/10.13031/2013.34089

Bechmann, M. E., Kleinman, P. J., Sharpley, A. N., \& Saporito, L. S. (2005). Freeze-thaw effects on phosphorus loss in runoff from manured and catch-cropped soils. J. Environ. Qual, 34, 2301-2309. https://doi.org/10.2134/jeq2004.0415

Brye, K. R., Andraski, T. W., Jarrell, W. M., Bundy L. G., \& Norman J. M. (2002). Phosphorus leaching under a 
restored tallgrass prairie and corn agroecosystems. J. Environ. Qual, 31, 769-781. https://doi.org/10.2134/jeq2002.0769

Butler, J. S., \& Coale, F. J. (2005). Phosphorus leaching in manure-amended Atlantic Coastal Plain soils. J. Environ. Qual, 34, 370-381.

Cade-Menun, B. J., Bell, G., Baker-Ismail, S., Fouli, Y., Hodder, K., McMartin, D. W., Perez-Valdivia, C., \& Wu, K. S. (2013). Nutrient loss from Saskatchewan cropland and pasture in spring snowmelt runoff. Can. J. Soil Sci., 93, 445-468. https://doi.org/10.4141/cjss2012-042

Campbell, C. A., Read, D. W. L., Winkleman, G. E., \& McAndrew, D. W. (1984). $1^{\text {st }} 12$ years of a long-term crop-rotation study in southwestern Saskatchewan-bicarbonate-P distribution in soil and P-uptake by the plant. Can. J. Soil Sci, 64, 125-137. https://doi.org/10.4141/cjss84-012

Chanasyk, D. S., \& Woytowich, C. P. (1987). Sediment yield as a result of snowmelt runoff in the Peace River region. Can. Agric. Eng, 29, 1-6.

Converse, J. C., Bubenzer, G. D., \& Paulson, W. H. (1976). Nutrient losses in surface run-off from winter spread manure. Trans. ASAE, 19, 517-519. https://doi.org/10.13031/2013.36061

Cutforth, H. W., McConkey, B. G., Woodvine, R. J., Smith, D. G., Jefferson, P. G., \& Akinremi, O. O. (1999). Climate change in the semiarid prairie of southwestern Saskatchewan: Late winter-early spring. Can. J. Plant Sci, 79, 343-350. https://doi.org/10.4141/P98-137

Fleming, R., \& Fraser, H. (2000). Impacts of winter spreading of manure on water quality: Literature Review. Ridgetown College, Univ. of Guelph, Ridgetown, ON, Canada.

Gallichand, J. (1994). Numerical simulations of steady-state subsurface drainage with vertically decreasing hydraulic conductivity. Irrigation and Drainage Systems, 8, 1-12. https://doi.org/10.1007/BF00880794

Ginting, D., Moncrief, J. F., Gupta, S. C., \& Evans, S. D. (1998). Interaction between manure and tillage system on phosphorus uptake and runoff losses. J. Environ. Qual, 27, 1403-1410. https://doi.org/10.2134/jeq1998.00472425002700060017x

Glozier, N. E., Elliott, J. A., Holliday, B., Yarotski, J., \& Harker, B. (2006). Water quality characteristics and trends in a small agricultural watershed: south Tobacco creek, Manitoba, 1992-2001. Environment Canada, Saskatoon, SK, Canada.

Granger, R. J., Gray, D. M., \& Dyck, G. E. (1984). Snowmelt infiltration to frozen prairie soils. Can. J. Earth Sci, 21, 669-677. https://doi.org/10.1139/e84-073

Guertal, E. A., Eckert, D. J., Traina, S. J., \& Logan, T. J. (1991). Differential phosphorus retention in soil profiles under no-till crop production. Soil Sci. Soc. Am. J, 55, 410-413. https://doi.org/10.2136/sssaj1991.03615995005500020020x

Hansen, N. C., Gupta, S. C., \& Moncrief, J. F. (2000). Snowmelt runoff, sediment, and phosphorus losses under three different tillage systems. Soil Till. Res, 57, 93-100. https://doi.org/10.1016/S0167-1987(00)00152-5

Jensen, M. B., Jorgensen, P. R., Hansen, H. C. B., \& Nielsen, N. E. (1998). Biopore mediated subsurface transport of dissolved orthophosphate. J. Environ. Qual, 27, 1130-1137. https://doi.org/10.2134/jeq1998.00472425002700050019x

Keeney, D. R., \& Nelson, D. W. (1982). Nitrogen - inorganic forms. Methods of soil analysis. Part 2. Chemical and microbiological properties: 643-698.

Klausner, S. D., Zwerman, P. J., \& Ellis, D. F. (1976). Nitrogen and phosphorus losses from winter disposal of dairy manure. J. Environ. Qual, 5, 47-49. https://doi.org/10.2134/jeq1976.00472425000500010010x

Kongoli, C. E., \& Bland, W. L. (2002). Influence of manure application on surface energy and snow cover: Field experiments. J. Environ. Qual, 31, 1166-1173. https://doi.org/10.2134/jeq2002.1166

Kumaragamage, D., Flaten, D., Akinremi, O. O., Sawka, C. \& Zvomuya, F. (2011). Soil test phosphorus changes and phosphorus runoff losses in incubated soils treated with livestock manures and synthetic fertilizer. Can. J. Soil Sci, 91, 375-384. https://doi.org/10.4141/cjss10004

Lake Winnipeg Stewardship Board. (2006). Reducing nutrient loading to Lake Winnipeg and its watershed: Our collective responsibility and commitment to action. Report to the

Langdale, G. W., Leonard, R. A., \& Thomas, A. W. (1985). Conservation practice effects on phsophorus losses from southern piedmont watersheds. J. Soil Water Conserv, 40, 157-161. 
Li, S., Elliott, J. A., Tiessen, K. H., Yarotski, J., Lobb, D. A., \& Flaten, D. N. (2011). The effects of multiple beneficial management practices on hydrology and nutrient losses in a small watershed in the Canadian prairies. J. Environ. Qual, 40, 1627-1642. https://doi.org/10.2134/jeq2011.0054

Little, J. L., Nolan, S. C., Casson, J. P., \& Olson, B. M. (2007). Relationships between soil and runoff phosphorus in small Alberta watersheds. J. Environ. Qual, 36, 1289-1300. https://doi.org/10.2134/jeq2006.0502

McConkey, B. G., Ulrich, D. J., \& Dyck, F. B. (1997). Snow management and deep tillage for increasing crop yields on a rolling landscape. Can. J. Soil Sci, 77, 479-486. https://doi.org/10.4141/S96-080

Minister of Water Stewardship. Lake Winnipeg Stewardship Board, Gimli, MB. www.lakewinnipeg.org/web/downloads/LWSB_December_2006_Report_3.pdf. Accessed July 23, 2012.

Mooleki, S. P., Schoenau, J. J., Hultgreen, G., Wen, G., \& Charles J. L. (2002). Effect of rate, frequency and method of liquid swine manure application on soil nitrogen availability, crop performance and $\mathrm{N}$ use efficiency in east-central Saskatchewan. Can. J. Soil Sci, 82, 457-467. https://doi.org/10.4141/S01-057

Mueller, D. H., Wendt, R. C., \& Daniel, T. C. (1984). Phosphorus losses as affected by tillage and manure application. Soil Sci. Soc. Am. J, 48, 901-905. https://doi.org/10.2136/sssaj1984.03615995004800040040x

Ontkean, G. R., Chanasyk, D. S., \& Bennett, D. R. (2005). Snowmelt and growing season phosphorus flux in an agricultural watershed in south-central Alberta, Canada. Water Qual. Res. J. Canada, 40, 402-417.

Priyashantha, K. R. S., Maule, C. P., \& Elliott, J. A. (2007). Influence of slope position and hog manure injection on fall soil $\mathrm{P}$ and $\mathrm{N}$ distribution in an undulating landscape. Trans. ASABE, 50, 45-52. https://doi.org/10.13031/2013.22410

Qian, P., Schoenau, J. J., \& Karamanos, R. E. (1994). Simultaneous extraction of available phosphorus and portassium with a new soil test - a modification of Kelowna extraction. Comm. Soil Sci. Plant Anal, 25, 627-635. https://doi.org/10.1080/00103629409369068

SAS Institute, Inc. (2008). SAS user's guide. Statistics (Version 9, ed). Cary, NC, USA: SAS Institute Inc.

Saskatchewan Soil Survey. (1989). Rural Municipality of Humboldt No. 370. Preliminary soil map and report. Saskatchewan Institute of Pedology, University of Saskatchewan, Saskatoon, SK, Canada.

Schnepf, M., \& Cox, C. (2006). Environmental benefits of conservation on cropland: the status of our knowledge. Soil and Water Conservation Society, Ankeny.

Schoenau, J. J., \& Davis, J. G. (2006). Optimizing soil and plant responses to land-applied manure nutrientsin the Great Plains of North America. Can. J. Soil Sci, 86, 587-595. https://doi.org/10.4141/S05-115

Sharpley, A. N., \& Smith, S. J. (1994). Wheat tillage and water quality in the southern plains. Soil Till. Res, 30, 33-48. https://doi.org/10.1016/0167-1987(94)90149-X

Sharpley, A. N., McDowell, R. W., \& Kleinman, P. J. A. (2001). Phosphorus loss from land to water: integrating agricultural and environmental management. Plant Soil, 237, 287-307. https://doi.org/10.1023/A:1013335814593

Sharpley, A. N., Withers, P. J. A., Abdalla, C. W., \& Dodd, A. R. (2005). Strategies for the sustainable management of phosphorus. American Society of Agronomy, Madison, WI, USA.

Sharpley, A., \& Moyer, B. (2000). Phosphorus forms in manure and compost and their release during simulated rainfall. J. Environ. Qual, 29, 2053-2053. https://doi.org/10.2134/jeq2000.00472425002900060056x

Sims, J. T., Simard, R. R. \& Joern, B. C. (1998). Phosphorus loss in agricultural drainage: Historical perspective and current research. J. Environ. Qual, 27, 277-293. https://doi.org/10.2134/jeq1998.00472425002700020006x

Smith, A., Schoenau, J., Lardner, H. A., \& Elliott, J. (2011). Nutrient export in run-off from an in-field cattle overwintering site in East_central Saskatchewan. Water Sci. Tech, 64, 1790-1795. https://doi.org/10.2166/wst.2011.747

Stamm, C., Fluhler, H., Gachter, R., Leuenberger, J., \& Wunderli, H. (1998). Preferential transport of phosphorus in drained grassland soils. J. Environ. Qual, 27, 515-522. https://doi.org/10.2134/jeq1998.00472425002700030006x

Stark, J. M., \& Firestone, M. K. (1996). Kinetic characteristics of ammonium-oxidizer communities in a California oak woodland-annual grassland. Soil Biol. Biochem, 28, 1307-1317. 
https://doi.org/10.1016/S0038-0717(96)00133-2

Steenhuis, T. S., Muck, R. E., Bubenzer, G. D., \& Converse, J. C. (1981). Modelling nutrient runofflosses from winter spread manure. Livestock waste: a renewable resource, 281-285.

Stumborg, C., \& Schoenau, J. J. (2008). Evaluating phosphorus loading from repeated manure applications to two Saskatchewan soils. Can. J. Soil Sci, 88, 377-387. https://doi.org/10.4141/S06-048

Stumborg, C., Schoenau, J. J., \& Malhi, S. S. (2007). Nitrogen balance and accumulation pattern in three contrasting prairie soils receiving repeated applications of liquid swine and solid cattle manure. Nutr. Cycl. Argoecosys, 78, 15-25. https://doi.org/10.1007/s10705-006-9071-5

Tiessen, K. H., Elliott, J. A., Yarotski, J., Lobb, D. A., Flaten, D. N., \& Glozier, N. E. (2010). Conventional and conservation tillage: Influence on seasonal runoff, sediment, and nutrient losses in the Canadian prairies. $J$. Environ. Qual, 39, 964-980. https://doi.org/10.2134/jeq2009.0219

Vadas, P. A., Haggard, B. E., \& Gburek, W. J. (2005). Predicting dissolved phosphorus in runoff from manured field plots. J. Environ. Qual, 34, 1347-1353. https://doi.org/10.2134/jeq2004.0424

Vadas, P. A., Meisinger, J. J., Sikora, L. J., McMurtry, J. P., \& Sefton, A. E. (2004). Effect of poultry diet on phosphorus in runoff from soils amended with poultry manure and compost. J. Environ. Qual, 33, 1845-1854. https://doi.org/10.2134/jeq2004.1845

Valipour, M. (2012a). A comparison between horizontal and vertical drainage systems (include pipe drainage, open ditch drainage, and pumped wells) in Anisotropic soils. J. Mech. Civil Engineer, 4, 7-12. https://doi.org/10.9790/1684-0410712

Valipour, M. (2012b). Hydro-module determination for Vanaei village in Eslam Abad G harb, Iran. J. Agric. Biol. Sci., 7, 968-976.

Valipour, M. (2013a). Evolution of irrigation-equipped areas as share of cultivated acres. Irrigat. Drainage Sys. Eng.

Valipour, M. (2013b). Increasing irrigation efficiency by management strategies: cutback and surge irrigation. $J$. Agric. Biol. Sci., 8, 35-43.

Valipour, M. (2016). How much meteorological information is necessary to achieve reliable accuracy for rainfall estimations? Agriculure J., 53.

Valipour, M., \& Singh, V. P. (2016). Global experiences on wastewater irrigation: challeneges and prospects. In: Balanced urban development: options and strategies for liveable cities. Maheshwari, B, Singh, V. P., Thoradeniya, B. (eds.) (2016). Springer Open. Sydney, Australia. https://doi.org/10.1007/978-3-319-28112-4_18

Van Vliet, L. J. P., \& Hall, J. W. (1991). Effects of two crop rotations on seasonal runoff and soil loss in the Peace river region. Can. J. Soil Sci, 71, 533-544. https://doi.org/10.4141/cjss91-051

Young, R. A., \& Mutchler, C. K. (1976). Pollution potential of manure spread on frozen ground. J. Environ. Qual, 5, 174-179. https://doi.org/10.2134/jeq1976.00472425000500020013x

Zhao, S. L., Gupta, S. C., Huggins, D. R., \& Moncrief, J. F. (2001). Tillage and nutrient source effects on surface and subsurface water quality at corn planting. J. Environ. Qual, 30. 998-1008.https://doi.org/10.2134/jeq2001.303998x

Zuzel, J. F., \& Pikul, J. L. (1987). Infiltration into a seasonally frozen agricultural soil. J. Soil Water Concerv, 42, 447-450.

\section{Copyrights}

Copyright for this article is retained by the author(s), with first publication rights granted to the journal.

This is an open-access article distributed under the terms and conditions of the Creative Commons Attribution license (http://creativecommons.org/licenses/by/3.0/). 